\title{
AerChemMIP: quantifying the effects of chemistry and aerosols in CMIP6
}

\author{
William J. Collins ${ }^{1}$, Jean-François Lamarque ${ }^{2}$, Michael Schulz ${ }^{3}$, Olivier Boucher $^{4}$, Veronika Eyring ${ }^{5}$, Michaela \\ I. Hegglin ${ }^{1}$, Amanda Maycock ${ }^{6}$, Gunnar Myhre ${ }^{7}$, Michael Prather ${ }^{8}$, Drew Shindell ${ }^{9}$, and Steven J. Smith ${ }^{10}$ \\ ${ }^{1}$ Department of Meteorology, University of Reading, Reading, RG6 6BB, UK \\ ${ }^{2}$ National Center for Atmospheric Research, Boulder, CO, USA \\ ${ }^{3}$ Norwegian Meteorological Institute, Oslo, Norway \\ ${ }^{4}$ Laboratoire de Météorologie Dynamique, IPSL, Université Pierre et Marie Curie/CNRS, Paris, France \\ ${ }^{5}$ Deutsches Zentrum für Luft- und Raumfahrt, Institut für Physik der Atmosphäre, Oberpfaffenhofen, Germany \\ ${ }^{6}$ School of Earth and Environment, University of Leeds, Leeds, UK \\ ${ }^{7} \mathrm{CICERO}$ - Center for International Climate and Environmental Research Oslo, Oslo, Norway \\ ${ }^{8}$ University of California, Irvine, CA, USA \\ ${ }^{9}$ Nicholas School of the Environment, Duke University, Durham, NC 27708, USA \\ ${ }^{10}$ Joint Global Change Research Institute, Pacific Northwest National Laboratory, 5825 University Research Court, Suite \\ 3500, College Park, MD 20740, USA
}

Correspondence to: William J. Collins (w.collins@ reading.ac.uk)

Received: 1 June 2016 - Discussion started: 12 July 2016

Revised: 16 December 2016 - Accepted: 4 January 2017 - Published: 9 February 2017

\begin{abstract}
The Aerosol Chemistry Model Intercomparison Project (AerChemMIP) is endorsed by the Coupled-Model Intercomparison Project 6 (CMIP6) and is designed to quantify the climate and air quality impacts of aerosols and chemically reactive gases. These are specifically near-term climate forcers (NTCFs: methane, tropospheric ozone and aerosols, and their precursors), nitrous oxide and ozonedepleting halocarbons. The aim of AerChemMIP is to answer four scientific questions.
\end{abstract}

1. How have anthropogenic emissions contributed to global radiative forcing and affected regional climate over the historical period?

2. How might future policies (on climate, air quality and land use) affect the abundances of NTCFs and their climate impacts?

3. How do uncertainties in historical NTCF emissions affect radiative forcing estimates?

4. How important are climate feedbacks to natural NTCF emissions, atmospheric composition, and radiative effects?
These questions will be addressed through targeted simulations with CMIP6 climate models that include an interactive representation of tropospheric aerosols and atmospheric chemistry. These simulations build on the CMIP6 Diagnostic, Evaluation and Characterization of Klima (DECK) experiments, the CMIP6 historical simulations, and future projections performed elsewhere in CMIP6, allowing the contributions from aerosols and/or chemistry to be quantified. Specific diagnostics are requested as part of the CMIP6 data request to highlight the chemical composition of the atmosphere, to evaluate the performance of the models, and to understand differences in behaviour between them.

\section{Introduction}

\subsection{Motivation for AerChemMIP}

Aerosols and chemically reactive gases in the atmosphere can exert important influences on global and regional air quality and climate. Scientific questions and uncertainties regarding chemistry-climate interactions are relevant to regional-scale climate change (e.g. tropospheric ozone and 
aerosols interacting with regional meteorology), to longrange connections (e.g. hemispheric transport of air pollution, the impacts of lower stratospheric ozone and temperatures on surface climate) and globally integrated effects (e.g. the lifetimes of methane $\left(\mathrm{CH}_{4}\right)$ and nitrous oxide $\left.\left(\mathrm{N}_{2} \mathrm{O}\right)\right)$.

Past climate change has been forced by a wide range of chemically reactive gases, aerosols and well-mixed greenhouse gases (WMGHGs), in addition to carbon dioxide. More specifically, anthropogenic effects on methane, aerosol and ozone abundances (also known as near-term climate forcers, NTCFs) are estimated to have been responsible for a climate forcing that is presently nearly equal in magnitude to that of $\mathrm{CO}_{2}$ (Shindell et al., 2013a; Myhre et al., 2013a). These emissions are thought to have led to a variety of global climate impacts including changes in regional patterns of temperature and precipitation (Rotstayn et al., 2015). In addition, NTCF forcing is inherently spatially inhomogeneous (Shindell et al., 2013a), which leads to regional responses, particularly for aerosols, and there is some evidence that the global climate response to a regional-scale NTCF differs from that of an equivalent globally homogeneous radiative forcing (Shindell et al., 2012b, 2015). Changes in the abundance of NTCFs can also induce rapid adjustments in meteorological quantities (such as atmospheric temperature, water vapour, clouds) through radiative heating/cooling and/or effects on precipitation and cloud lifetime (Sherwood et al., 2015). These adjustments are in principle independent of surface temperature changes (although in practical model configurations the land surface temperature will also respond). The contribution of such rapid adjustments to the change in Earth's energy budget following a perturbation of a radiatively active species can be incorporated into an effective radiative forcing (ERF) (Myhre et al., 2013a; Boucher et al., 2013; Sherwood et al., 2015), which has been shown to be a better predictor of the eventual surface temperature change than the traditional instantaneous or stratosphere-adjusted definitions of radiative forcing.

NTCFs were also identified in the Intergovernmental Panel on Climate Change 5th Assessment Report (IPCC AR5 Myhre et al., 2013a) as the main source of uncertainty in the total anthropogenic ERF since pre-industrial times. In particular, natural aerosols originating from biogenic sources, dust or sea salt are primary contributors to the uncertainty in present-day aerosol forcing (Carslaw et al., 2013). This is because the response of the climate system to humaninduced aerosol perturbations depends critically on the natural aerosol background (Carlton et al., 2010; Gordon et al., 2016), due in part to the non-linear response of aerosol-cloud interactions.

The forcing of climate by ozone changes has resulted from increases in ozone driven by changes in nitric oxides $\left(\mathrm{NO}_{x}\right)$, carbon monoxide $(\mathrm{CO})$ and volatile organic compound (VOC) emissions and methane abundance (mostly affecting the troposphere) and decreases in ozone driven by ozone depleting substances (ODSs), such as chloroflu- orocarbons (CFCs) and hydrochlorofluorocarbons (HCFCs) (mostly affecting the stratosphere) (Shindell et al., 2013b). The net ERF due to ozone is primarily the result of multiple emission changes. For example, one of the largest components of the ERF due to past methane emissions comes from the associated increase in tropospheric ozone (Prather et al., 2001; Stevenson et al., 2013). In addition, stratospheric ozone losses due to ODSs since the 1970s have led to a significant cooling of the stratosphere (Shine et al., 2003; McLandress et al., 2015), and the Antarctic ozone hole is linked to changes in tropospheric circulation and rainfall patterns in the Southern Hemisphere, especially during austral summer (WMO, 2014). In the Southern Hemisphere, future changes in summertime tropospheric circulation are expected to be controlled by both the rates of ozone recovery and WMGHG increases (McLandress et al., 2011; Polvani et al., 2011), indicating the need to account for ozone changes in future climate projections.

IPCC AR5 (Kirtman et al., 2013) found large uncertainties in projecting the future chemical composition of the atmosphere and climate insofar as it affects climate and air quality. Natural and managed ecosystems provide a large fraction of the methane and nitrous oxide emissions, and also emit aerosol and ozone precursors (e.g. through emissions of soil nitrogen oxides, biogenic volatile organic compounds, and wildfires). These sources are likely to be affected by climate change, leading to a variety of feedbacks (Arneth et al., 2010) that to date have only been quantified from a limited number of studies (and models) and thus there is a need for a coordinated set of simulations that allows for a consistent and clean comparison between models. For example, the CMIP5 Atmospheric Chemistry and Climate Model Intercomparison Project (ACCMIP) focusing on chemistry had only three model results that could be used to assess climateair quality links (Schnell et al., 2016).

NTCF precursor emissions are also responsible for driving regional and local air quality (Fiore et al., 2012). This has led to the recognition that a combined mitigation policy for climate change and air pollution has clear economic benefits compared to separate mitigation (Clarke et al., 2014). Most, if not all, scenarios for the future actions of societies lead to changes in the emissions and meteorology that determine air quality and create pollution episodes. The exposure risks to human health and assets (agriculture, built environment, ecosystems) will be driven by daily variations in surface ozone and particulate matter in addition to deposition of nitrate and sulfate and any interactions of atmospheric and land-use changes. CMIP6 will provide comprehensive information on the future large-scale evolution of atmospheric composition, thus updating the knowledge base used to manage air pollution.

The Aerosol and Chemistry Model Intercomparison Project, AerChemMIP, contributes to CMIP6 by diagnosing climate forcings and feedbacks involving NTCFs and chemically reactive WMGHGs (collectively, tropospheric 
aerosols and ozone, their precursors, methane, nitrous oxide, some halocarbons and impacts on stratospheric ozone), documenting and understanding past and future changes in the chemical composition of the atmosphere, and estimating the global-to-regional climate response from these changes.

Improving our insight and understanding of the inner functioning of climate models and climate itself is a primary motivation for AerChemMIP. To characterise the overall ERF from all species, including NTCFs, requires extra efforts and has not been properly done in earlier CMIP experiments (Forster et al., 2016). Climate feedback processes that involve changes to the atmospheric composition of reactive gases and aerosols may affect the temperature response to a given WMGHG concentration level. Better exploration and documentation of the changes in atmospheric composition in a changing climate is of interest for many other purposes such as choosing among different air quality mitigation options or understanding perturbations to ecosystems and biogeochemical cycles. Finally, uniform evaluation of the models will expose systematic biases and better constrain our overall goal of quantifying the role of aerosols and reactive gases in climate forcing.

\subsection{Previous work}

The contribution of tropospheric ozone precursors to radiative forcing (through changes in ozone and methane) has been considered in successive IPCC assessments since IPCC (1994) and the Second Assessment Report (IPCC, 1996), where a combination of 2-D and 3-D chemistry models was used (PhotoComp in Olson et al., 1997). A more rigorous intercomparison of 3-D chemistry transport models (OxComp in Prather et al., 2001; Gauss et al., 2003) provided information on the geographical distribution of ozone forcing for the IPCC Third Assessment Report (Ramaswamy et al., 2001). The IPCC Fourth Assessment report (AR4) (Forster et al., 2007) again used a multi-model framework (Atmospheric Composition Change European Network - ACCENT) to calculate maps of ozone radiative forcing (Gauss et al., 2006). Here the models were still nearly all offline chemistry transport models, and none of the climate models used in AR4 (those participating in the CMIP3 project) included tropospheric ozone chemistry. The radiative forcing of ozone in all cases was calculated using offline radiative transfer models, usually for "pre-industrial", "present" and one or two future time slices. It was not until the CMIP5 project that a few of the climate models included interactive tropospheric chemistry. The aim of ACCMIP (Lamarque et al., 2013) was to quantify the contribution of ozone and aerosols to the radiative forcing in the CMIP5 models that included these components. In practice, the model setups for CMIP5 and ACCMIP were usually different (the ACCMIP models tended to have lower resolution but include greater complexity in chemistry and aerosols) so that ACCMIP was not able to fully characterise the forcings of most simulations submitted to the CMIP5 archive. ACCMIP combined the results from chemistry-climate models (CCMs) and offline chemistry transport models (CTMs) to quantify the central estimate and range of historical and future ozone and aerosol forcings, air quality, and the contributions of individual ozone precursor emissions. Surface ozone diagnostics in ACCMIP were used to evaluate CCM ability to match current air quality episodes and predict future ones (Schnell et al., 2015, 2016). NTCF forcings were diagnosed using a mixture of offline radiative transfer models and double-call diagnostics, whereby a model radiation scheme is called twice, with the second call containing one or all radiative species set to fixed values.

The historical and future climate effects of ozone depletion were first addressed in multi-model studies using CTMs in ACCENT (Gauss et al., 2006; Forster et al., 2007), focussing on changes in global radiative forcing. Son et al. (2008) highlighted the specific impact of the Antarctic ozone hole on regional surface climate by contrasting CMIP3 models with and without prescribed stratospheric ozone changes, and by comparing them to online CCMs from the SPARC Chemistry-Climate Model Validation Activity phase 1 (CCMVal-1; Eyring et al., 2007), with followon studies using model simulations from the CCMVal phase 2 (Son et al., 2010; SPARC, 2010; WMO, 2010, 2014). Most of the CCMs included stratospheric chemistry only, while the newer generation CCMs available now encompass both tropospheric and stratospheric chemistry, with a few of these models being coupled to an ocean (John et al., 2012; Lamarque et al., 2013; Shindell et al., 2013c; Morgenstern et al., 2016). The most recent comprehensive assessment of the performance of these CCMs regarding stratospheric and tropospheric chemistry and dynamics is currently being performed within the SPARC/IGAC ChemistryClimate Model Initiative (CCMI; Eyring et al., 2013a). In contrast to CMIP3, where half of the models prescribed a constant stratospheric ozone climatology, the CMIP5 models all considered time-varying ozone either prescribed or calculated interactively (Eyring et al., 2013b). This has led to substantial improvements in the representation of climate forcing by stratospheric ozone in climate models since the AR4 (Flato et al., 2013). The importance of "whole atmosphere" chemistry-climate coupling for the climate effects of ozone has also been recently highlighted, since changes in stratospheric ozone abundances, e.g. due to changes in ozone depleting substances, can affect tropospheric ozone through stratosphere-to-troposphere exchange (Shindell et al., 2013b; Banerjee et al., 2016).

The radiative forcing from historical aerosol emissions was quantified on the basis of one model (Langner and Rodhe, 1991) in IPCC (1994) and the Second Assessment Report (IPCC, 1996). The effects started to be included online in some climate models by the Third Assessment Report (Penner et al., 2001), but CTMs continued to play an important role even in the Fourth and Fifth Assessment Reports. Radiative forcing estimates for anthropogenic aerosol 
components were largely derived from a multimodel ensemble through the Aerosol Comparison (AeroCom) initiative (Schulz et al., 2006; Myhre et al., 2013b). AeroCom is a long-standing activity of aerosol model intercomparison (Textor et al., 2006; Kinne et al., 2006; Schulz et al., 2006), which provided estimates of radiative forcings from a large set of global aerosol (mostly offline) models for AR4 and AR5. The complex path from precursor emissions to aerosol loads, to optical and cloud-perturbing properties, to finally forcing has been simulated with well-documented diversity (Schulz et al., 2006; Myhre et al., 2013b; Ghan et al., 2016). More recently, aerosol forcing was quantified in ACCMIP, with many models using the same setups as used in CMIP5. These results were combined with additional simulations under CMIP5 to quantify the central estimate and range of historical to present-day aerosol forcing. Future forcing estimates relied solely on ACCMIP (Shindell et al., 2013a). It was problematic in CMIP5 to properly quantify the ERF by aerosols in the historic period and future scenarios, in most GCM models. This was mainly due to missing experiments, diagnostics and insufficiently characterised feedbacks involving natural aerosols.

Since the ERF calculations for ozone (tropospheric and stratospheric) and aerosols in ACCMIP were decoupled from the CMIP5 climate model simulations that informed the IPCC AR5 chapters on climate change (Bindoff et al., 2013; Kirtman et al., 2013; Collins et al., 2013), this made it difficult to relate the temperature responses to radiative forcing due to NTCFs and also to constrain the climate sensitivity. AerChemMIP is designed to fill in this information gap to inform IPCC AR6. The lessons learned in AeroCom, ACCMIP, and CCMI largely contributed to the design of AerChemMIP.

\section{Science questions}

This section provides the scientific justification for the four science questions that AerChemMIP will address. As a multi-model exercise, AerChemMIP will identify areas of consensus and disagreement in the answers. Owing to the strong connection between clouds and aerosols (Boucher et al., 2013), AerChemMIP will provide crucial information to support the World Climate Research Program (WCRP) Grand Challenge on "Clouds, Circulation and Climate sensitivity". In addition, through the importance of natural sources for WMGHGs and NTCFs, the proposed research questions in AerChemMIP are well aligned with WCRP theme "Biogeochemical forcings and feedbacks". The AerChemMIP proposal focuses on four broad questions, listed and discussed below.

\subsection{How have anthropogenic emissions contributed to global radiative forcing and affected regional climate over the historical period?}

Anthropogenic non- $\mathrm{CO}_{2}$ emissions (e.g. NTCFs, in addition to other WMGHGs like halocarbons and nitrous oxide) have led to a climate forcing that is commensurate to the $\mathrm{CO}_{2}$ forcing in some regions, especially over the last few decades (Myhre et al., 2013a). There are many couplings between different chemically and radiatively active species that remain to be fully understood. For example, in addition to its direct climate forcing of $0.48 \pm 0.05 \mathrm{~W} \mathrm{~m}^{-2}$ (Myhre et al., 2013a), methane acts as a precursor to tropospheric ozone (Prather et al., 1994; Fiore et al., 2012), and is a dominant sink of the hydroxyl radical $(\mathrm{OH})$, the primary tropospheric oxidising agent (Naik et al., 2013). As such, changes in methane emissions will also affect the lifetime of $\mathrm{CH}_{4}$ and related gases (Prather, 1994) and the formation of aerosols through oxidation of anthropogenic and natural precursors (Shindell et al., 2009). Methane directly affects the chlorine chemistry of stratospheric ozone depletion (Pawson et al., 2014). Furthermore, methane is a source of water vapour in the stratosphere; this is an important contributor to stratospheric ozone depletion, especially away from the polar regions. Stratospheric water vapour is also a greenhouse gas and changes in methane thus have a further indirect radiative forcing (Myhre et al., 2013a). As the methane concentration has more than doubled since pre-industrial times (from $722 \pm 25 \mathrm{ppb}$ in 1750 to $1803 \pm 2 \mathrm{ppb}$ by 2011), it is imperative to quantify its historical forcing and the combined climate impacts associated with those changes. Furthermore, the ERF due to ozone and aerosol changes since pre-industrial times is a key factor behind the large uncertainty in constraining climate sensitivity using observations of the historical record.

The ERF due to NTCFs has an inhomogeneous spatial distribution. The degree of regional temperature and precipitation responses due to such heterogeneous forcing remains an open question within the scientific community. There is also evidence that NTCFs, which are primarily located over Northern Hemisphere midlatitude land areas, have led to a larger climate response, both there and globally, relative to the more homogeneous ERF from WMGHGs (Shindell, 2014; Shindell et al., 2015; Rotstayn et al., 2015; Marvel et al., 2016). Climate response to regional forcings is not limited to the region of origin, and remote responses have been clearly demonstrated in numerical experiments (Teng et al., 2012; Levy et al., 2013; Bollasina et al., 2013; Shindell et al., 2015). In particular, the position of the inter-tropical convergence zone (ITCZ) has been shown to depend on the differential rate of aerosol forcing between hemispheres (Hwang et al., 2013).

A detectable regional response to inhomogeneous climate forcing concerns the Southern Hemisphere summertime surface circulation changes which have been induced by the Antarctic ozone hole as an indirect response to stratospheric 
ozone depletion from increasing halocarbons. These changes have been argued to lead to changes in the subtropical jet position, rainfall patterns, ocean circulation, and possibly sea ice cover (Arblaster and Meehl, 2006; McLandress et al., 2011; Polvani et al., 2011). The relative role of these ozoneinduced changes for observed Southern Hemisphere summertime climate compared to other anthropogenic forcings and natural variability is not fully resolved by the scientific community, with some contradictory studies in particular for the Antarctic sea ice response (WMO, 2014). Hence there is a need for a multi-model ensemble of simulations that resolve stratospheric chemistry to isolate the role of stratospheric ozone depletion.

\subsection{How might future policies (on climate, air quality and land use) affect the abundances of NTCFs and their climate impacts?}

In the upcoming decades, policies that will impact atmospheric chemistry can be categorised into three broad areas: (1) climate change policies targeting mostly WMGHG emissions, (2) air quality policies targeting mostly NTCF emissions affecting tropospheric aerosols and ozone, and (3) landuse policies and practices. AerChemMIP aims to identify the patterns of chemical change at the global and regional levels, as well as the ERF associated with NTCF mitigation efforts (focusing on policy choices in areas 1 and 2 above) and their impact on climate (surface temperature and precipitation) and other environmental change (health, ecosystem, visibility, etc.) between 2015 and 2055 (as the time frame over which aerosol and precursor emissions are expected to be significant; Shindell et al., 2012a; Fiore et al., 2015). Such impact analysis can be performed by contrasting two simulations: (a) a reference with weak air quality policies and relatively high aerosol and ozone precursor emissions; and (b) a perturbation experiment where strong air quality policies are applied, leading to much reduced NTCF emissions. These perturbations are designed in collaboration with ScenarioMIP to ensure that the NTCF perturbations are consistent with the underlying storylines (see Sect. 3.2). A comparison of the reference and perturbation simulation will provide the background for understanding the effects of air quality policies over the next few decades. Analysis of results from these simulations will be critical to understand the interactions between NTCFs (aerosols in particular) and weather systems (Jacob and Winner, 2009; Leibensperger et al., 2012).

\subsection{How do uncertainties in historical NTCF emissions affect radiative forcing estimates?}

The primary focus of this question is to understand the sensitivity of present-day ERF to uncertainties in estimates of historical NTCF emissions. Indeed, while all proposed simulations rely on the usage of a central estimate, it is clear that there is a range of emission estimates (as discussed in Granier et al., 2011; Smith et al., 2011; Bond et al., 2013) that needs to be considered. Time-slice ERFs (pre-industrial to present-day) for each NTCF or precursor species emitted are proposed in Sect. 3.3. These ERFs can be scaled with the uncertainty in emission to provide information on this contribution to the NTCF forcing uncertainty. Due to the nonlinearities in the system, this is likely to provide an upper bound. While this uncertainty will clearly be region, sector and species dependent, it would be beyond the scope of this project to explore the full spectrum of variations. Results from the simulations can be directly compared to the simulations in Sect. 3.1 and analysed for differences in radiative forcing as well as air quality and overall atmospheric composition. Inter-model differences will document their varying sensitivities to emissions.

\subsection{How important are climate feedbacks to natural NTCF emissions, atmospheric composition, and radiative effects?}

In a recent assessment of 28 modelled factors that could be a source of uncertainty in simulated cloud brightness, Carslaw et al. (2013) identified that, in their model, approximately $45 \%$ of the variance came from natural aerosols, especially from dimethysulfide (DMS) and volcanic $\mathrm{SO}_{2}$ emissions. This can be compared with $34 \%$ of the variance due to anthropogenic aerosols. Additional studies have highlighted the role of marine biogenic aerosols (McCoy et al., 2015) and isoprene emissions (Archibald et al., 2010) in biogeochemical feedbacks. These are all examples of couplings and potential climate feedbacks involving diverse biogeochemical cycles and terrestrial (Isaksen et al., 2009; Arneth et al., 2010) and marine ecosystems (Cameron-Smith et al., 2011). AerChemMIP therefore proposes to quantify the climate impacts associated with specific biogeochemical cycles. To do this it will be necessary to quantify the climate response to the heterogeneous forcing patterns from naturally emitted short-lived species (the climate responses to WMGHGs are already covered in Sect. 2.1). Six different feedbacks will be examined: (1) dust emissions, (2) sea-salt emissions, (3) DMS emissions, (4) fire emissions, (5) $\mathrm{NO}_{x}$ emissions from lightning, and (6) biogenic VOC emissions. Each will have a specified perturbation experiment. The comparison of each simulation with the CMIP DECK (Diagnostic, Evaluation and Characterization of Klima) pre-industrial control experiment (Eyring et al., 2016a) will enable a quantification of the importance of the considered climate-emission feedbacks.

\section{Experimental design}

The AerChemMIP experiments focus primarily on understanding atmospheric composition changes (from NTCFs and other chemically active anthropogenic gases) and their 
impact on climate. We have devised a series of experiments that enable the forcing of various NTCFs to be contrasted with that of WMGHGs for historical and future climate change. In addition, the proposed chemistry-climate simulations will enable diagnosis of changes in regional air quality through changes in surface ozone and particulate matter. The effective radiative forcings are calculated from the net top of atmosphere (TOA) flux difference between atmosphereonly simulations with identical SSTs but differing composition (Forster et al., 2016; Pincus et al., 2016). The climate responses are calculated from the differences in climate between atmosphere-ocean simulations with differing composition.

AerChemMIP is designed to quantify the climate effects of interactive aerosols, tropospheric chemistry and stratospheric chemistry. Ideally participating models will include all three components; however, we realise that this may not always be possible or practical. Many CMIP models include emission-driven interactive aerosol schemes, but with limited or no further tropospheric chemistry. To understand their overall behaviour we encourage such models to participate in those AerChemMIP experiments that are relevant to quantifying the climate effects of the aerosols. For models with tropospheric chemistry, but lacking a stratospheric chemistry, we encourage participation in all experiments except those explicitly addressing the effects of halocarbons. For tropospheric-only chemistry, the CMIP6-specified stratospheric ozone dataset should be used (Hegglin et al., 2017). Modelling groups with full chemistry and aerosol models are encouraged to perform all simulations they deem relevant to their objectives. Note that, for consistency, the concentrations of chemically and radiatively active species should be the same in the radiation and chemistry schemes. Tables 1 to 6 list the minimum model configurations required for each experiment. The suffix "CHEM" ${ }^{\mathrm{T}}$ " or " $\mathrm{CHEM}^{\mathrm{S}}$ " indicates interactive tropospheric or stratospheric chemistry is the minimum needed for these experiments. The suffix "AER" indicates that interactive aerosols are needed. For models without interactive tropospheric chemistry, the Tier $1 \ldots N T C F$ and Tier 2 ... Aer simulations will be identical, and so only need to be run once. Models capable of running with both interactive chemistry and aerosols should do so for all experiments.

To participate in AerChemMIP, climate models must be run for the CMIP DECK and CMIP6 historical (atmosphereocean simulation with forcings evolving over 1850-2014) experiments with the same setup as in AerChemMIP, i.e. with the same levels of sophistication activated in the chemistry and aerosol schemes, and with the AerChemMIP diagnostics as specified in Sect. 4. It is likely that groups will first spin up their model to pre-industrial conditions without interactive chemistry. This would then be followed by a shorter spinup with fully interactive chemistry for as long as is needed to ensure the chemistry does not introduce any additional drift. This process will be quicker if the non-chemistry spinup uses ozone and oxidants from a prior run of the interac- tive chemistry model (e.g. Collins et al., 2011). The length of piControl (or esm-piControl) needs to be at least as long as the experiments. For AerChemMIP this is 205 years (164 years historical +41 years future), although note that Eyring et al. (2016a) recommend 500 years. It is necessary to have CMIP6 historical simulations with the same chemistry and aerosols as in AerChemMIP as this is used as the baseline. The AerChemMIP configured abrupt-4xCO2 should be run for at least 150 years as recommended in Eyring et al. (2016a), to quantify the climate-chemistry feedbacks. It is recommended that modelling groups document the aerosol and chemistry schemes in their climate model and evaluate their performance in the DECK AMIP simulation.

The emissions of anthropogenic aerosols and reactive species are provided by Hoesly et al. (2017) (http:// www.globalchange.umd.edu/ceds/ceds-cmip6-data/). Models should use their own schemes for natural emissions. The WMGHGs (methane, nitrous oxide, halocarbons) will be specified as CMIP-specified concentrations, either throughout the troposphere or at the surface.

We also realise that valuable contributions to answering the AerChemMIP scientific questions can be made by groups unable to participate in CMIP6, such as those running offline CTMs. Participation from these groups is welcomed and encouraged in the wider Chemistry-Climate Model Initiative (CCMI; Eyring et al., 2013b) and AeroCom projects, but the data will not form part of the official CMIP6 submission.

We have arranged the experiments into three tiers to reflect their priority. Tier 1 experiments are those necessary to answer science questions 1 and 2 in terms of overall impacts of NTCFs and reactive well-mixed gases. Tier 2 experiments will answer question 4 and provide further detail on questions 1 and 2 by separating the effects of aerosol and ozone precursors. Tier 3 experiments will contribute to question 3 and provide additional detail and speciation. The total simulation years requested are 1265 for Tier 1, 1369 for Tier 2 and 270 for Tier 3, split between coupled-ocean and fixed SST experiments. This includes 30 years for a pre-industrial fixed SST control in common with RFMIP. In addition, models should have been run for the DECK experiments (501 years excluding control). Finally, modelling groups interested in studying the climate and air quality impacts of future emission reduction will need to perform a three-member ensemble of SSP3-7.0 as described in ScenarioMIP (O'Neill et al., 2016) (41 years for each member).

\subsection{Historical (in support of science question 2.1)}

These experiments are designed to quantify the contributions of aerosols (tropospheric) and ozone (tropospheric and stratospheric) to climate change over the historical period. For aerosol and tropospheric ozone precursor emissions the model simulations will span 1850-2014, and for halocarbons the simulations will span 1950-2014, since halocarbons only significantly increased after 1950 . The latter experiments will 
Table 1. List of historical coupled-ocean experiments. Experiments cover the period between 1850 and 2014, except hist-1950HC, which starts in 1950. The "AER" suffix means models should at least calculate tropospheric aerosols driven by emission fluxes. The "CHEM ${ }^{\mathrm{S} \text { " }}$ suffix means at least stratospheric chemistry is required. Models should always be run with the maximum complexity available. The species columns refer to the specifications for concentrations $\left(\mathrm{CH}_{4}, \mathrm{~N}_{2} \mathrm{O}\right.$ and $\left.\mathrm{CFC} / \mathrm{HCFC}\right)$ or emissions (aerosol and ozone precursors). "Hist" means the concentrations or emissions should evolve as for the CMIP6 historical simulation; a year means the concentrations or emissions should be fixed to that year. Three ensemble members are requested for each experiment.

\begin{tabular}{llllllll}
\hline Experiment ID & $\begin{array}{l}\text { Minimum model } \\
\text { configuration }\end{array}$ & $\mathrm{CH}_{4}$ & $\mathrm{~N}_{2} \mathrm{O}$ & $\begin{array}{l}\text { Aerosol } \\
\text { precursors }\end{array}$ & $\begin{array}{l}\text { Ozone } \\
\text { precursors }\end{array}$ & CFC/HCFC & Tier \\
\hline hist-piNTCF & AOGCM AER & Hist & Hist & 1850 & 1850 & Hist & 1 \\
hist-piAer & AOGCM AER & Hist & Hist & 1850 & Hist & Hist & 2 \\
hist-1950HC $^{\text {AOGCM CHEM }}{ }^{\text {A }}$ & Hist & Hist & Hist & Hist & 1950 & 1 \\
\hline
\end{tabular}

enable the evaluation of the relative role of ozone depletion compared to other anthropogenic forcings and natural variability in determining past changes in Southern Hemisphere summertime climate (WMO, 2014). Methane and nitrous oxide have indirect climate effects as their chemistry affects tropospheric ozone production, stratospheric ozone chemistry, aerosol oxidation, and the lifetimes of each other.

The historical increases in aerosols and tropospheric ozone have inhomogeneous spatial distributions, and the degree of regional temperature and precipitation responses to such heterogeneous forcing remains an open question within the scientific community which these experiments and their pairwise ERF experiments described in Sect. 3.1.2 should help to answer. These will also enable the community to quantify whether NTCF emissions, which are primarily located over Northern Hemisphere midlatitude land areas have led to a larger climate response there, relative to forcing from WMGHGs (Shindell, 2014). To distinguish between the warming effects of ozone and the net cooling effect of aerosols, further experiments separate the two groups. We choose to allocate $\mathrm{NO}_{x}$ to the ozone precursor group (as this is where it has the largest climate impact) even though it will generate both ozone and nitrate aerosol in models.

The experimental setup has been designed to pair coupledocean simulations with specified SST atmosphere-only experiments to calculate the ERFs due to each category of forcing agent (see Sect. 3.1.2 for more details). Comparison between the temperature and precipitation changes in the coupled-ocean simulations with the ERFs (top of atmosphere, and surface) will provide information on the efficacies of the forcings to drive changes in climate.

\subsubsection{Transient historical coupled-ocean simulations}

These simulations parallel historical which is a simulation from 1850 to 2014 with all forcings applied (Eyring et al., 2016a), and differ only by fixing the anthropogenic emissions or concentrations of a specified class of species. All other forcing agents must evolve as in historical. Perturbations to the total NTCF emissions (hist-piNTCF) or aerosol component (hist-piAer) start at the same point in the 1850 control as historical with the anthropogenic emissions fixed at that point. Perturbations to the halocarbon ODSs branch from the historical run at 1950 with chlorofluorocarbon and hydrochlorofluorocarbon concentrations fixed at that point (hist-1950HC), as specified in Table 1.

The individual climate signals from the proposed perturbations are likely to be small compared to internal climate variability, therefore we request at least three ensemble members for each experiment, using different ensemble members of historical as the starting points. The climate impacts of the anthropogenic emissions of NTCFs, aerosols and ozonedepleting halocarbons can then be diagnosed by subtracting the perturbed runs from the historical climate and evaluated against internal variability diagnosed from piControl. For models without interactive chemistry, hist-piNTCF and hist-piAer are identical and the same ozone climatology as historical should be used. Note that the climate signal from aerosols and reactive gas perturbations will include biogeochemical feedbacks via climate impacts on emissions, chemistry and transport of constituents, which requires further experiments and diagnostics described below in Sect. 3.4.

The total simulation years requested for this set of experiments are 684 for Tier 1 and 492 for Tier 2 .

\subsubsection{Transient historical prescribed SST simulations}

In order to calculate the transient ERFs that drive the above climate changes, a set of simulations repeats the above sensitivity runs in Sect. 3.1.1, but using atmosphere-only configurations with prescribed sea-surface temperatures (SSTs) and sea ice. The SSTs and sea ice should be specified as the monthly mean time-evolving values from one ensemble member of the historical simulations. This differs from the usual definition of ERF where the SSTs are specified to be a fixed repeating climatology throughout the simulation, usually taken from a pre-industrial control experiment. Including evolving SSTs means that the underlying climate state is consistent with the historical simulation that is used as the reference for all these experiments. Use of historical SSTs rather than pre-industrial SSTs will eliminate any effects of using an inconsistent background climate state (such as dif- 
Table 2. List of historical prescribed SST experiments. Experiments cover the period between 1850 and 2014, except histSST-1950HC, which starts in 1950. The "AER" suffix means models should at least calculate tropospheric aerosols driven by emission fluxes. The "CHEM" ${ }^{\mathrm{T}}$ " or

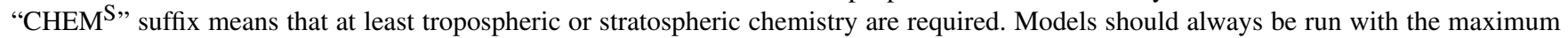
complexity available. The species columns refer to the specifications for concentrations $\left(\mathrm{CH}_{4}, \mathrm{~N}_{2} \mathrm{O}\right.$ and $\left.\mathrm{CFC} / \mathrm{HCFC}\right)$ or emissions (aerosol and ozone precursors). "Hist" means the concentrations or emissions should evolve as for the CMIP6 historical simulation; a year means the concentrations or emissions should be fixed to that year. Note that the $\mathrm{N}_{2} \mathrm{O}$ and $\mathrm{HC}$ runs will have a small forcing, but will provide valuable information on their historical impacts on stratospheric ozone changes.

\begin{tabular}{|c|c|c|c|c|c|c|c|}
\hline Experiment ID & $\begin{array}{l}\text { Minimum model } \\
\text { configuration }\end{array}$ & $\mathrm{CH}_{4}$ & $\mathrm{~N}_{2} \mathrm{O}$ & $\begin{array}{l}\text { Aerosol } \\
\text { precursors }\end{array}$ & $\begin{array}{l}\text { Ozone } \\
\text { precursors }\end{array}$ & $\mathrm{CFC} / \mathrm{HCFC}$ & Tier \\
\hline histSST & AGCM AER & Hist & Hist & Hist & Hist & Hist & 1 \\
\hline histSST-piNTCF & AGCM AER & Hist & Hist & 1850 & 1850 & Hist & 1 \\
\hline histSST-piAer & AGCM AER & Hist & Hist & 1850 & Hist & Hist & 2 \\
\hline histSST-piO3 & AGCM CHEM $^{\mathrm{T}}$ & Hist & Hist & Hist & 1850 & Hist & 2 \\
\hline histSST-1950HC & $\mathrm{AGCM} \mathrm{CHEM}^{\mathrm{S}}$ & Hist & Hist & Hist & Hist & 1950 & 1 \\
\hline histSST-piCH4 & AGCM CHEM $^{\mathrm{T} / \mathrm{S}}$ & 1850 & Hist & Hist & Hist & Hist & 1 \\
\hline histSST-piN2O & AGCM CHEM $^{\mathrm{S}}$ & Hist & 1850 & Hist & Hist & Hist & 2 \\
\hline
\end{tabular}

ferent cloud cover and natural emissions) that could affect concentrations of aerosols and reactive species and the transient ERFs. The impact of background state on the diagnosis of ERFs is likely to be small (Forster et al., 2016). This is further discussed in Sect. 5.1. The control simulation (histSST) uses prescribed historical SSTs with all other components as historical. This is not likely to be significantly different from the coupled-ocean historical simulation, but we request this simulation for consistency with the rest of the experiments. There are Tier 2 experiments to calculate separately the transient ERFs from aerosol and ozone precursors, as specified in Table 2.

The total simulation years requested are 556 for Tier 1 and 492 for Tier 2.

Historical changes in methane and nitrous oxide abundances have altered atmospheric chemistry and the NTCF radiative forcing. These indirect effects are complex and have previously been calculated in piecemeal ways (Myhre et al., 2013a). In AerChemMIP, the historical transient ERFs will be calculated for models that have reactive gas chemistry (at least tropospheric). The transient ERF pattern from these simulations is expected to be relatively homogeneous, although their chemical effects on ozone and secondary aerosols may be less so. Therefore, AerChemMIP does not include any experiments to derive the climate responses to methane or nitrous oxide forcing. The climate response to homogeneous forcing is quantified in Detection and Attribution Model Intercomparison Project (DAMIP) from the hist$G H G$ simulation (as historical, but only the WMGHG forcings evolve).

The transient ERFs for each species or group of species will be diagnosed by subtracting the top of atmosphere and surface radiative fluxes in the perturbed runs from those in histSST. For models without interactive chemistry, histSSTpiNTCF and histSST-piAer are identical, and the same ozone climatology as histSST should be used.

\subsection{Future simulations (in support of science question 2.2)}

AerChemMIP further aims to identify the patterns of change in surface temperature and precipitation at the global and regional levels associated with future NTCF mitigation efforts focusing on air pollutant species. These experiments cover the time frame from 2015 to 2055 , as this is when reductions in aerosol and ozone precursor emissions are expected to be significant, at least for some regions. The future scenarios are based on Shared Socio-economic Pathways (SSPs) as described in O'Neill et al. (2014) and van Vuuren et al. (2014). As well as socio-economic scenarios, the SSPs include representations of different levels of controls on air quality pollutants - weak, medium and strong (Table 3). The medium strength of pollution control corresponds to following current legislation (CLE) until 2030 and progressing three-quarters of the way towards maximum technically feasible reduction (MTFR) thereafter. The rate of progress is different for high, medium and low-income countries. Strong pollution control exceeds CLE and progresses ultimately towards MTFR. Weak pollution controls assume delays to the implementation of CLE and make less progress towards MTFR than the medium scenario. For more details, see Rao et al. (2017). To detect the largest signal we choose the reference scenario to be SSP3-7.0 "Regional Rivalry" without climate policy $\left(7.0 \mathrm{~W} \mathrm{~m}^{-2}\right.$ at 2100 , experiment $s s p 370$ ), see Fujimori et al. (2017), as this has the highest levels of short-lived climate pollutants and "Weak" levels of air quality control measures (O'Neill et al., 2016; Rao et al., 2017). The ssp370 ScenarioMIP simulation will need to have been run with the AerChemMIP setup and diagnostics, or repeated here. The data for the perturbation experiment to this within AerChemMIP will be generated by the Asia-Pacific Integrated Modeling (AIM) group using the same socio-economic scenario as in Fujimori et al. (2017), but with "Strong" levels of air qual- 
Table 3. Qualitative framework for pollution control in the SSPs, based on Rao et al. (2017) Table 2.

\begin{tabular}{|c|c|c|c|}
\hline \multirow{2}{*}{$\begin{array}{l}\text { Policy } \\
\text { strength }\end{array}$} & \multicolumn{2}{|c|}{ Policy targets } & \multirow[t]{2}{*}{ Technological innovation } \\
\hline & High-income countries & $\begin{array}{l}\text { Medium- and low-income } \\
\text { countries }\end{array}$ & \\
\hline Strong & $\begin{array}{l}\text { Aim for much lower } \\
\text { pollutant levels than } \\
\text { current targets. }\end{array}$ & $\begin{array}{l}\text { Comparatively quick catch-up } \\
\text { with the developed world }\end{array}$ & $\begin{array}{l}\text { Pollution control technology } \\
\text { costs drop substantially, with } \\
\text { control performance increasing. }\end{array}$ \\
\hline Medium & $\begin{array}{l}\text { Lower than current } \\
\text { targets }\end{array}$ & $\begin{array}{l}\text { Catch-up with the developed } \\
\text { world, but not as quickly as } \\
\text { "Strong" }\end{array}$ & $\begin{array}{l}\text { Continued modest technology } \\
\text { advances }\end{array}$ \\
\hline Weak & $\begin{array}{l}\text { Regionally varied } \\
\text { policies }\end{array}$ & $\begin{array}{l}\text { Trade barriers and/or institu- } \\
\text { tional limitations substantially } \\
\text { slow progress in pollution con- } \\
\text { trol. }\end{array}$ & $\begin{array}{l}\text { Lower levels of technological } \\
\text { advance overall }\end{array}$ \\
\hline
\end{tabular}

ity control measures SSP3-7.0-lowNTCF. The energy use and levels of climate mitigation are the same in these two scenarios. Levels of WMGHGs (including methane) will be unchanged unless they are directly affected by the air quality control measures. Differences in climate, transient ERF, chemical composition and air quality between the two scenarios will be solely due to the alternative air quality control measures. SSP3-7 does run out until 2100 as part of ScenarioMIP but, to save computation expense, AerChemMIP is only requesting simulations out to 2055. This is the time period over which the divergence in air quality policies is expected to be largest.

\subsubsection{Transient future coupled ocean}

The two transient future coupled-ocean experiments start in January 2015 from the end of the historical simulation and are run for 41 years (to December 2055) following the SSP3-7.0 and SSP3-7.0-lowNTCF scenarios for WMGHG and NTCF emissions (experiments ssp370 and ssp370-lowNTCF; see Fig. 1 and Table 4). Note that the ssp370 reference simulation is the same as in ScenarioMIP; it is therefore required that ScenarioMIP ssp370 is performed using the same model configuration as for AerChemMIP. The climate and air quality signals will be derived by subtracting the experiment ("clean"; see Tables 4 and 5) from the reference. This signal is expected to be globally small (commensurate with a forcing of the order of $0.1 \mathrm{~W} \mathrm{~m}^{-2}$, although much larger locally), so at least three ensemble members for both SSP3-7 and SSP3-7-lowNTCF variants are requested as continuation from existing historical ensemble members. Where natural emissions are modelled interactively, these will vary with the evolving climate and will differ between ssp370 and ssp370-lowNTCF as the climate diverges.

The total simulation years requested are 123 (all Tier 1).

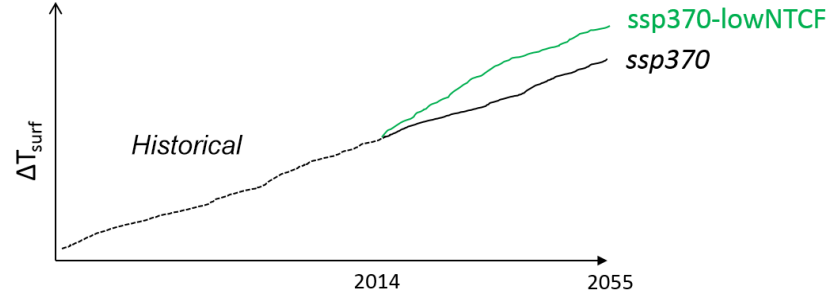

Figure 1. Schematic of future coupled-ocean simulations based on the SSP3-7.0 scenario.

\subsubsection{Transient future prescribed SST simulations}

As for the historical experiments (Sect. 3.1), the above scenarios (SSP3-7.0 and SSP3-7.0-lowNTCF) are repeated with prescribed SSTs. These SSTs (and sea ice) are taken from the monthly mean evolving values from one of the ensemble members of the coupled ssp370 run. The differences in radiative fluxes between the reference and "clean" simulations will give the TOA and atmospheric transient ERFs. Comparison between the magnitudes and patterns of transient ERF with surface temperature and precipitation from the previous coupled model simulations will provide quantification of the efficacy of the NTCFs to affect climate.

The contributions of the different groups of NTCFs to future climate will be quantified by further simulations in which only a subset of the emissions (aerosols, ozone precursors, black carbon) follow the "clean" scenario, with the rest following the reference SSP3-7.0. All these perturbation experiments are Tier 2 (see Fig. 2 and Table 5). An additional scenario SSP3-7.0-lowCH4 will differ from the control SSP3-7.0 only in using lower emission factors for methane.

The ssp370SST-ssp126Lu experiment will study the atmospheric chemical impacts of land-use changes through natural emissions (biogenic VOCs, fire, dust) and surface up- 
Table 4. List of future coupled-ocean experiments. Experiments cover the period 2015 to 2055. The "AER" suffix means models should at least calculate tropospheric aerosols driven by emission fluxes. Interactive chemistry should be active if available. Models should always be run with maximum complexity. The species columns refer to the specifications for concentrations $\left(\mathrm{CH}_{4}\right)$ or emissions $($ aerosol and ozone precursors). "Reference" means the concentrations or emissions should evolve as for SSP3-7.0; "Clean" means the concentrations or emissions should evolve following a version of SSP3-7.0 with cleaner air quality policies. CFC/HCFC concentrations should follow the SSP3-7.0 scenario in both cases. Three ensemble members are requested for each experiment.

\begin{tabular}{|c|c|c|c|c|c|}
\hline Experiment ID & $\begin{array}{l}\text { Minimum model } \\
\text { configuration }\end{array}$ & $\mathrm{CH}_{4}$ & $\begin{array}{l}\text { Aerosol } \\
\text { precursors }\end{array}$ & $\begin{array}{l}\text { Ozone } \\
\text { precursors }\end{array}$ & Tier \\
\hline $\operatorname{ssp} 370^{*}$ & AOGCM AER & Reference & Reference & Reference & 1 \\
\hline ssp370-lowNTCF & AOGCM AER & Reference & Clean & Clean & 1 \\
\hline
\end{tabular}

* ssp370 is also specified as Tier 1 in ScenarioMIP.

Table 5. List of future prescribed SST simulations. Experiments cover the period 2015 to 2055. The "AER" suffix means models should at least calculate tropospheric aerosols driven by emission fluxes. The "CHEM" suffix means that at least interactive tropospheric chemistry is required. Models should always be run with the maximum complexity available. The species columns refer to the specifications for concentrations $\left(\mathrm{CH}_{4}\right)$ or emissions (aerosol and ozone precursors). "Reference" means the concentrations or emissions should evolve as for SSP3-7.0; "Clean" means the concentrations or emissions should evolve following a version of SSP3-7.0 with cleaner air quality policies. CFC/HCFC concentrations should follow the SSP3-7.0 scenario in all cases. For ssp370SST-lowLu the land-use mask from the SSP1-2.6 scenario should be used for the interactive natural emission schemes (and for the climate); anthropogenic emissions should follow the SSP37.0 scenario.

\begin{tabular}{|c|c|c|c|c|c|}
\hline Experiment ID & $\begin{array}{l}\text { Minimum model } \\
\text { configuration }\end{array}$ & $\mathrm{CH}_{4}$ & $\begin{array}{l}\text { Aerosol } \\
\text { precursors }\end{array}$ & $\begin{array}{l}\text { Ozone } \\
\text { precursors }\end{array}$ & Tier \\
\hline ssp370SST & AGCM AER & Reference & Reference & Reference & 1 \\
\hline ssp370SST-lowNTCF & AGCM AER & Reference & Clean & Clean & 1 \\
\hline ssp370SST-lowAer & AGCM AER & Reference & Clean & Reference & 2 \\
\hline ssp370SST-lowBC & AGCM AER & Reference & Reference (non BC) Clean (BC) & Reference & 2 \\
\hline ssp370SST-lowO3 & AGCM CHEM $^{\mathrm{T}}$ & Reference & Reference & Clean & 2 \\
\hline ssp370SST-lowCH4 & AGCM CHEM $^{\mathrm{T}}$ & Low & Reference & Reference & 2 \\
\hline ssp370SST-ssp126Lu & AGCM AER & Reference & \multicolumn{2}{|c|}{ Reference (anthropogenic) } & 2 \\
\hline
\end{tabular}

take for models that include interactive schemes for emission and deposition. Not all models will model all these processes interactively. The simulation will be parallel to ssp370SST using the same WMGHGs and anthropogenic NTCF emissions, but with land use specified according to the SSP12.6 scenario. The transient ERFs calculated with respect to the ssp370SST control will include the effects of albedo changes as well as NTCFs. The pair ssp370SST-ssp370SSTssp126Lu are the prescribed SST equivalents of the coupledocean Land Use Model Intercomparison Project (LUMIP) pair ssp370-ssp370-ssp126Lu (Lawrence et al., 2016).

The total simulation years requested are 82 for Tier 1 and 205 for Tier 2 .

\subsection{Time-slice historical ERF simulations (in support of science questions 2.1 and 2.3)}

The quantification of pre-industrial to present-day ERFs due to different drivers (such as in Myhre et al., 2013a, Fig. 8.17) is used widely. The AerChemMIP time-slice experiments will provide the data to generate a consistent table of presentday ERFs for the reactive gases and aerosols. The ERFs

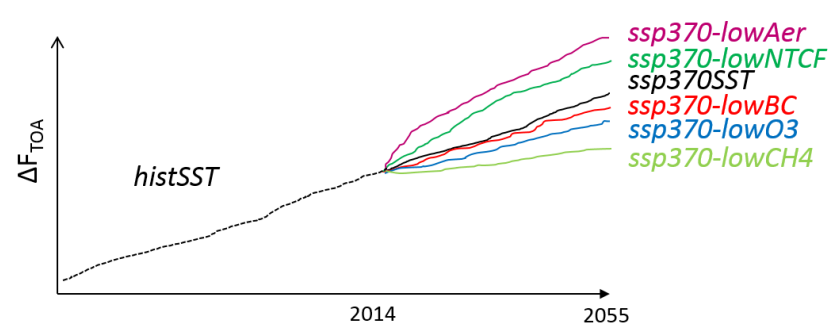

Figure 2. Schematic of future prescribed SST simulations based on the SSP3-7.0 scenario.

are calculated by comparing the change in net TOA radiation fluxes between two runs with the same prescribed SSTs, but with NTCF emissions or WMGHG (methane, nitrous oxide, halocarbon) concentrations perturbed from their pre-industrial to present-day values. Internal variability (mainly clouds) generates considerable interannual variability in ERFs; therefore, at least 30 years of simulation are needed to characterise the present-day ERF from some species (Forster et al., 2016). These simulations differ from the transient ERF simulations in Sect. 3.1.2 in that they use 
Table 6. List of fixed SST ERF simulations. These are time-slice experiments of 30 years in total, using pre-industrial climatological average SST and sea ice distributions. The "AER" suffix means that models should at least calculate tropospheric aerosols driven by emission fluxes. The "CHEM" ${ }^{\mathrm{T}}$ " or "CHEM ${ }^{\mathrm{S}}$ " suffix means that at least tropospheric or stratospheric chemistry is required. Models should always be run with the maximum complexity available. The species columns refer to the specifications for concentrations $\left(\mathrm{CH}_{4}, \mathrm{~N}_{2} \mathrm{O}\right.$ and $\left.\mathrm{CFC} / \mathrm{HCFC}\right)$ or emissions (aerosol and ozone precursors). A year means the concentrations or emissions should be fixed to that year.

\begin{tabular}{|c|c|c|c|c|c|c|c|}
\hline Experiment ID & $\begin{array}{l}\text { Minimum model } \\
\text { configuration }\end{array}$ & $\mathrm{CH}_{4}$ & $\mathrm{~N}_{2} \mathrm{O}$ & $\begin{array}{l}\text { Aerosol } \\
\text { precursors }\end{array}$ & $\begin{array}{l}\text { Ozone } \\
\text { precursors }\end{array}$ & $\mathrm{CFC} / \mathrm{HCFC}$ & Tier \\
\hline piClim-control $^{*}$ & AGCM-AER & 1850 & 1850 & 1850 & 1850 & 1850 & 1 \\
\hline piClim-NTCF* & AGCM- ${ }^{\mathrm{T}}$ AER & 1850 & 1850 & 2014 & 2014 & 1850 & 1 \\
\hline piClim-aer & AGCM-AER & 1850 & 1850 & 2014 & 1850 & 1850 & 2 \\
\hline piClim-BC & AGCM-AER & 1850 & 1850 & 1850 (non-BC) $2014(\mathrm{BC})$ & 1850 & 1850 & 2 \\
\hline piClim-O3 & AGCM-CHEM $^{\mathrm{T}}$ & 1850 & 1850 & 1850 & 2014 & 1850 & 2 \\
\hline piClim-CH4 & AGCM-CHEM $^{\mathrm{T} / \mathrm{S}}$ & 2014 & 1850 & 1850 & 1850 & 1850 & 1 \\
\hline piClim-N2O & AGCM-CHEM $^{\mathrm{S}}$ & 1850 & 2014 & 1850 & 1850 & 1850 & 2 \\
\hline piClim-HC & AGCM-CHEM $^{\mathrm{S}}$ & 1850 & 1850 & 1850 & 1850 & 2014 & 1 \\
\hline piClim-NOX & AGCM-CHEM $^{\mathrm{T}}$ & 1850 & 1850 & 1850 & $\begin{array}{l}1850\left(\text { non- }-\mathrm{NO}_{x}\right) \\
2014\left(\mathrm{NO}_{x}\right)\end{array}$ & 1850 & 3 \\
\hline piClim-VOC & AGCM-CHEM $^{\mathrm{T}}$ & 1850 & 1850 & 1850 & $\begin{array}{l}1850 \text { (non-CO/VOC) } \\
2014 \text { (CO/VOC) }\end{array}$ & 1850 & 3 \\
\hline piClim-SO2 & AGCM-AER & 1850 & 1850 & 1850 (non-SO2) 2014 (SO2) & 1850 & 1850 & 3 \\
\hline piClim-OC & AGCM-AER & 1850 & 1850 & 1850 (non-OC) 2014 (OC) & 1850 & 1850 & 3 \\
\hline piClim-NH3 & AGCM-AER & 1850 & 1850 & 1850 (non-NH3) 2014 (NH3) & 1850 & 1850 & 3 \\
\hline
\end{tabular}

* piClim-control is identical to that in RFMIP; piClim-NTCF is identical to piClim-aerO3 (in RFMIP) for models with interactive tropospheric and stratospheric chemistry.

pre-industrial SSTs and maintain the same emissions (or concentrations) for 30 years. They therefore give a more accurate representation of the pre-industrial to present-day ERF than would be obtained from using portions of the transient historical ERF simulations.

The control simulation for these experiments will use 1850 concentrations of WMGHGs and emissions of NTCFs, run for 30 years in atmosphere-only mode with SSTs and sea ice prescribed as a (monthly varying) climatology taken from 30 years of the pre-industrial control (experiment piClimcontrol; see Table 6) following the Radiative Forcing Model Intercomparison Project (RFMIP) specification (Pincus et al., 2016). Provided this experiment is run with the same interactive chemistry and aerosols as the model configuration contributing to AerChemMIP, this will be the same control as in RFMIP. The TOA radiative fluxes from this control are expected to be very similar to the climatology from the coupled pre-industrial control. However, this extra simulation ensures consistency with the ERF definition and with RFMIP.

The perturbation experiments are run for 30 years following the control, using the same control SST and sea ice, but with the concentrations (for WMGHGs) or emissions (for short-lived species) of the selected species set to present-day (2014) values (Table 6). The WMGHG experiments should allow as complete a representation of the chemical effects on aerosol oxidation, tropospheric and stratospheric ozone, and stratospheric water vapour as the models are capable of. Note that in this setup methane concentrations are fixed and do not respond to changes in oxidation rate. The ozone ERF esti- mates are not broken down by their location (tropospheric or stratospheric), but whether they are driven by changes in ozone precursors or ODSs. Models without interactive chemistry should only run the aerosol specific experiments, and use the same ozone climatology as piClim-control.

The total simulation years requested are 120 for Tier 1 , 120 for Tier 2 and 150 for Tier 3.

\subsection{Natural emissions simulations (in support of science question 2.4)}

Climate change will affect the natural emissions of NTCFs and reactive WMGHGs. These natural emissions will have a radiative effect and so feed back onto climate change. To simplify the experimental setup, the experiments detailed here simply double the natural emissions. The radiative effects of natural WMGHGs (e.g. methane from natural sources) are not calculated as these can be obtained from experiment piClim-CH4. The control simulation is the 30-year 1850 fixed SST piClim-control as for the time-slice ERFs. Each experiment parallels the 30-year control, except that the emission fluxes from an interactive parameterisation are doubled (see Table 7). For models that do not interactively parameterise particular emissions, the fluxes from the 1850 climatological dataset should be doubled.

The radiative perturbation from these experiments will give ERF per $\mathrm{Tg} \mathrm{yr}^{-1}$ change in emissions. When scaled by the simulated changes in emission fluxes per $\mathrm{K}$ temperature change from either the DECK $4 \times \mathrm{CO}_{2}$ or $1 \% \mathrm{yr}^{-1} \mathrm{CO}_{2}$ sim- 
Table 7. List of fixed SST simulations for ERFs of natural emitted species. These are time-slice experiments of 30 years in total, using climatological average SST and sea ice distributions. The "AER" suffix means that at least interactive aerosols are required. The "CHEM ${ }^{\mathrm{T}}$ " suffix means that at least tropospheric chemistry is required. Models should always be run with the maximum complexity available. The specified natural emission flux should be doubled compared to the pre-industrial control, either scaling the parameterisations in an interactive scheme or the data files for specified emissions. All other forcing agents should be as in the pre-industrial control.

\begin{tabular}{lllc}
\hline Experiment ID & Minimum model configuration & Flux to be doubled & Tier \\
\hline piClim-2xdust & AGCM-AER & Dust & 2 \\
piClim-2xss & AGCM-AER & Sea salt & 2 \\
piClim-2xDMS & AGCM-AER & Oceanic DMS & 3 \\
piClim-2xfire & AGCM-AER & Fire $\left(\mathrm{NO}_{x}, \mathrm{BC}, \mathrm{OC}, \mathrm{CO}, \mathrm{VOCs} ..\right)$ & 3 \\
piClim-2xNOX & AGCM-CHEM & Lightning NO & 3 \\
piClim-2xVOC & AGCM-CHEM & Biogenic VOCs & 3 \\
\hline
\end{tabular}

ulations, these determine the feedback parameter given as $\mathrm{W} \mathrm{m}{ }^{-2}$ per $\mathrm{K}$ in surface temperature.

The total simulation years requested are 60 for Tier 2 and 120 for Tier 3 .

\section{Diagnostics}

The AerChemMIP-specific diagnostics are designed to answer the following questions. How large are forcing, feedback and response associated with reactive gases and aerosols in the models participating in CMIP6 historical and scenario simulations? Which processes and mechanisms need to be represented in the models for a credible description of climate-chemistry-aerosol interactions? How well do models reproduce the observed spatial distribution and historical evolution of NTCF concentrations, depositions, optical properties, and observable interactions with climate?

To guide the diagnostic process, the data request is structured according to overarching analysis subjects. These are detailed in the subsections below: Climate response, Forcing, Feedbacks, Chemistry-climate interactions, Air Quality, and Evaluation of model performance. Considerable experience has been gained in previous model intercomparison exercises (namely CCMVal, CCMI, AeroCom, ACCMIP, and Hemispheric Transport of Air Pollution (HTAP)), but all too often model versions were different from those used in CMIP. AerChemMIP provides a unique opportunity to generate a complete dataset, requested directly from those GCMs providing climate sensitivity and scenario information to CMIP6. A specific problem may be the expected diversity in model complexity, as mentioned in Sect. 3. Models may contain interactive aerosols, tropospheric chemistry, stratospheric chemistry and any combination of these. AerChemMIP requests all output unless unavailable from an individual model configuration with good reason.

The diagnostics requested for the AerChemMIP experiments are assembled in an Excel sheet in the supplementary material for this paper (also available at https://wiki.met.no/aerocom/aerchemmip/diagnostics), and the definitive and detailed request will be found in the CMIP6 data request (https://earthsystemcog.org/projects/ wip/CMIP6DataRequest). Since the AerChemMIP model versions are requested to also perform the DECK experiments, the data request contains suggestions for output limitations for these experiments (see the final data request for details). Here we provide an overview of the analysis subjects mentioned above. Suggestions for the best practice of diagnosing processes and outputting variables are given in some cases, in particular where previous model intercomparison projects failed to harmonise model output. The specific AerChemMIP request is grouped into eight tables and these are to be found in the Excel file and the CMIP6 data request: aerfixed (grid and land information), aermonthly-3d (essential monthly tracer and budget fields for all AerChemMIP simulations), aermonthly-2d (essential daily tracer fluxes, radiative forcing components and physical climate variables for all AerChemMIP simulations), aerdaily (boundary layer characterisation and ozone-aerosol diagnostics for evaluation), aerhourly (air quality index parameters), aer-6h (backscatter and extinction for aerosol vertical structure evaluation, dynamical parameters geopotential height and vorticity), aerzonal-vert and aerzonal (zonal mean gas concentrations for chemistry-climate interaction studies). Modellers are asked to read the explanatory notes found for each CF standard name on the CF website and the specific explanatory remarks in the AerChemMIP data request and corresponding Excel worksheet.

\subsection{Climate response}

The characterisation of the climate response to NTCF forcing requires a set of diagnostics, which are fairly standard to all CMIP experiments. They include the variables that altogether describe the state of the atmosphere, the ocean and cryosphere, and land surfaces including essential biosphere and carbon cycle parameters.

Specific attention should be devoted to the CFMIP Observation Simulator Package (COSP), which AerChemMIP models are encouraged to install. To facilitate the exploita- 
tion of A-train satellite data in numerical models, the COSP system has been developed that allows simulation of the signal that CloudSat and Cloud-Aerosol Lidar and Infrared Pathfinder Satellite Observation (CALIPSO) would see in a model-generated world. A better understanding of cloudaerosol interactions may be possible if models add specific diagnostic aerosol calls, which would allow analysis together with the COSP diagnostic package output. Of particular interest is the observable aerosol backscatter and extinction coefficient, which provides, since the arrival of the CALIOP satellite lidar in the A-train, a constraint for the global 3-D distribution of aerosols. Therefore modellers are asked to provide 3-D 6-hourly fields of aerosol extinction and backscatter coefficients for one realisation of the DECK Atmospheric Model Intercomparison Project (AMIP) experiment (1979-2014).

\subsection{Forcing}

For better documentation of which forcing is actually present in a given climate model, several sets of diagnostics are needed: (1) flux parameters providing ERF from fixed SST simulations, (2) 3-D mass mixing ratios and optical thickness in transient simulations, and (3) repeated aerosol-free calls to the radiation code (with aerosol scattering and absorption set to zero) in transient climate simulations (Ghan et al., 2012). This allows characterisation of the radiative forcing of the aerosol-radiation interaction and separation of it from the aerosol-cloud interactions and rapid adjustments. This is strongly recommended for the reference historical simulation and ERF time-slice experiments aimed at diagnosing aerosol forcing, but is not essential if it is not possible to implement. Combined with additional RFMIP diagnostics, this will generate a fairly complete forcing characterisation.

ERFs of gases and aerosols will be derived in the 30-year long fixed SST simulations (see Sect. 3) by investigating clear-sky and all-sky shortwave and longwave fluxes at the top of the atmosphere and at the surface. In the same simulations a range of auxiliary variables are requested which characterise emissions, 3-D mass or molar mixing ratios, aerosol optical properties and cloud properties to complement the radiative fluxes with actual composition diagnostics. With these, forcing efficiencies may be established to be used for the interpretation of transient simulations.

Characterising the atmospheric forcing in transient simulations of a fully coupled model poses problems, because the climate system response alters cloud cover, lapse rates, and even cryosphere and land surface properties. To first order and for most components atmospheric forcing is proportional to the amount of the species perturbing the pristine atmosphere - with the important exception of interactions involving clouds. Three-dimensional fields of mass mixing ratios and column integrated optical thickness for aerosol species allow tracking of the extent to which perturbations are present. For gaseous pollutants ozone molar mixing ra- tios and methane lifetime are requested in order to diagnose forcing offline.

Tracking the anthropogenic fraction of column loads would require additional tracers. For a first-order analysis, we will use anthropogenic-only emissions to compute the average anthropogenic fraction in transient simulations, as compared to the pre-industrial reference in 1850. Some emissions may include natural components, which may have changed along with climate change, such as $\mathrm{NO}_{x}$ from lightning and soil degradation and biogenic volatile organic compounds. We therefore request total emissions for each species for 1850 and 2014.

The 3-D fields of mass mixing ratios also provide the vertical distributions, which are useful for the understanding of forcing components (semi-direct, direct, cloud-aerosol interaction) of heterogeneously distributed species - in particular black carbon and other anthropogenic aerosols. Indeed, positive forcing (warming) and the semi-direct effect of black carbon have recently received more attention; 3-D fields of black carbon mass mixing ratios and column integrated absorption optical depth have been used widely for analysing the black carbon forcing efficiency.

A source of confusion has been the aerosol optical thickness (AOT) diagnostics (e.g. Flato et al., 2013, Fig. 9.29) in CMIP models. Natural (particularly dust and sea-salt) and anthropogenic aerosols have been blended together in different ways in models. We request output to diagnose the different aerosol species contributions to total AOT, and to provide more insight into the reasons for differences in AOT between models. If possible AOT should be output for sulfate, organic matter, dust, sea salt, black carbon, and nitrate at ambient relative humidity. In the case of internal mixed aerosol modes, total AOT shall be distributed according to the volume of the dry aerosol species present in the mixed aerosol mode. The sum of speciated AOT from all species simulated should be equal to total AOT at any given point in time and space.

Providing 3-D fields of mass mixing ratios and AOT consistently will allow analysis of differences in aerosol optical property calculations, as well as changes in aerosol humidity growth in a changing climate and with changing emission patterns. In combination with emissions in transient climate simulations these diagnostics will allow complete analysis of feedback processes; see below.

Another problem is which ambient humidity in the model is picked to compute AOT. Some models compute an all-sky AOT, including AOT in cloudy fractions with high humidities, while others restrict output to clear-sky AOT. The latter is preferred here, because it may be compared to that AOT which is observed under clear-sky conditions from satellites and sun photometers. Aerosol-radiation interactions are also most effective in clear-sky scenes, and it is thus more relevant to base forcing efficiencies on clear-sky AOT. If models compute normally an all-sky AOT using high relative humidities in cloudy fractions of the grid box, they are asked to also 
compute a clear-sky AOT (od550csaer) using clear-sky relative humidities.

Aerosol-cloud interactions are still among the most uncertain of forcing components. Here we have selected standard parameters which are also used in the Cloud Feedback Model Intercomparison Project (CFMIP) and which allow for a 3-D characterisation of cloud fraction, cloud liquid water path and cloud as well as ice number concentrations. The fixed SST approach can be further applied with additional radiation calls to diagnose the various aerosol-cloud effects (Ghan et al., 2012). Most models will provide all-sky and clear-sky radiative fluxes, by computing fluxes with a repeated double call to the radiation routine neglecting cloud scattering. Here we propose a repeated "aerosol-free" call invoking this all-sky/clear-sky double call to radiation once more, by setting the aerosol scattering and absorption properties to zero. Fluxes for this repeated call have to be stored separately (top-of-atmosphere radiative upwelling flux components with aerosol scattering and absorption set to zero: shortwave in all sky and clear sky (rsutca, rsutcsca) and corresponding longwave (rlutca, and rlutcsca)). To limit computational burden we propose to invoke this call during the DECK historical simulation and the piClim... experiments. In all cases, separate diagnostics for shortwave and longwave changes are applied.

\subsection{Feedbacks}

Feedback processes will change natural emissions of reactive gases and aerosols. The short-lived nature of dust, sea salt, biogenic gases and aerosols as well as reactive nitrogen components and ozone will exert a rapid feedback loop if triggered. Thorough documentation of natural emissions and 3-D fields of reactive gases and aerosols is needed.

To relate natural emission changes to forcing, specific experiments are designed in AerChemMIP which resemble the ERF experiments (see Table 7). In these feedback experiments radiation flux and cloud variables are requested as in the ERF forcing experiments. Other variables such as those characterising aerosol and cloud optical properties, and landsea ice distribution, will help with the analysis of processes (fires, dynamics, volcanic perturbation, land cover change, sea ice change) involved in the feedback process. Deposition of nutrients such as nitrogen and dust has been suspected to be involved in feedback processes (Collins et al., 2011). Their output is thus requested too.

\subsection{Chemistry-climate interactions}

Chemistry-climate interactions involve impacts of composition on climate (as discussed in Sect. 4.1), but also crucially the effect of climate change on atmospheric composition, which happens through both changes in transport and chemistry. The availability of stratosphere-troposphere resolving chemistry-climate model simulations thereby provides the unique opportunity to look at these chemistry-climate interactions in a more comprehensive way than what was hitherto possible based on the models contributing to CMIP5. The DECK Control and $1 \% \mathrm{yr}^{-1} \mathrm{CO}_{2}$ runs will be particularly valuable for this. The stratosphere has been identified as a potentially important contributor to model differences for both tropospheric ozone (Young et al., 2013) and the $\mathrm{OH}$ budget (Voulgarakis et al., 2013). Particular focus within AerChemMIP will be placed on the study of how physical climate parameters such as temperature, wind, clouds, and precipitation affect tropospheric composition and the oxidising capacity of the atmosphere in addition to changing emissions. To study and disentangle key processes that lead to model differences, a comprehensive list of monthly mean 3-D output of key meteorological parameters (standard variables temperature and precipitation, convective mass fluxes (mcu), lightning $\mathrm{NO}_{x}$ production (emilnox) and chemical species (also annual loss terms of methane, carbon monoxide, and nitrous oxide)) is requested. In addition, two transport tracers will help to track changes in tropospheric transport between hemispheres, the artificial tracers called aoa_nh and nh_50: the first one with a uniform source (1 year/year), constant in space and time, above the surface layer, $30-50^{\circ} \mathrm{N}$; the second one applying a uniform surface mixing ratio (100 pbbv), 30 $50^{\circ} \mathrm{N}$, with a 50-day exponential decay (see the definitions in the CCMI-1 data request at http://blogs.reading.ac.uk/ccmi/ data-requests-and-formats/). In the coupled tropospherestratosphere system, climate will affect tropospheric composition and also its oxidation capacity through changes in the stratospheric circulation and resulting changes in the stratospheric distribution of ozone and stratosphere-troposphere transport of ozone (Collins et al., 2003; Stevenson et al., 2006; Hegglin and Shepherd, 2009). A tagged stratospheric ozone variable (o3ste) is defined to diagnose stratospheretroposphere exchange, with the simulations hist-1950HC and histSST-1950HC designed to help disentangle the impact of ODSs and climate change on the stratospheric influence on tropospheric composition. Loss terms of $\mathrm{CO}$, methane, ozone and nitrous oxide are suggested to help interpretation of their budget in a changing climate.

\subsection{Air quality}

The simulations in AerChemMIP provide the opportunity to retrieve from historical and scenario runs air quality related parameters which relate the broadly used CMIP emissions to a transient description of climate to air quality metrics. An ensemble of models can be used to establish consequences for air quality. Most interest is on particulate matter concentrations and high ozone peaks. Since air pollution standards have been defined as exceedances for a given time window, we request hourly data at surface level for some few key substances, such as ozone, $\mathrm{PM}_{2.5}$ and $\mathrm{NO}_{2}$. From these frequencies of daily maximum, diurnal cycles in different climate regimes, boundary layer characteristics can be 
obtained, which do characterise the model also in terms of chemical reactivity but also with respect to boundary layer mixing. The output is required for the fully coupled historical and the two coupled SSP3-7.0 scenarios.

\subsection{Evaluation of model performance}

In addition to the above diagnostics focussed on the science questions, some variables will be used to specifically help to evaluate model performance. Testing model behaviour against observations is critical for gaining confidence in their simulation of the historical past and predictions of the future. The output requested refers to variables that have been observed by different observational networks (based on groundbased, balloon, aircraft or satellite sensors) over the recent past. Comparison to these data will enable investigation of model bias, but may also help to rank models with respect to their ability to capture critical variability (see for example SPARC CCMVal, 2010).

The diagnostics requested represent a subset of the diagnostics requested for the AeroCom and CCMI model comparison activities. These include 2-D hourly (surface level ozone, $\mathrm{PM}_{2.5}$, and $\mathrm{NO}_{2}$ ), 3-D monthly mean concentrations of aerosol species, ozone and ozone precursors (including methane, $\mathrm{CO}, \mathrm{NO}_{2}, \mathrm{OH}$, and VOCs), column data (ozone), AOTs at different wavelengths, and deposition rates (including wet and dry deposition of nitrates and sulfates, dust, and BC). The hourly and 6-hourly model output (contained in aerhourly and aer-6h tables) is requested specifically for the DECK AMIP simulations (1979-2014) and is not needed for other experiments. The other variables are included as being essential for forcing, feedback, chemistry-climate interactions and air quality analysis. Outputting such variables will hence serve multiple purposes.

Of particular importance are variables as assembled in the framework of the Global Atmospheric Watch (GAW) and observations for Model Intercomparison Projects (obs4MIP) (Teixeira et al., 2014; Ferraro et al., 2015). In addition, other datasets such as from the SPARC Data Initiative (Hegglin et al., 2017) for the stratosphere and from the ESA CCI (Hollmann et al., 2013) for the troposphere will be valuable for comparisons. Note that both CCMI and AeroCom will contribute with their model evaluation experience and will feed selected observational data sources into the Earth System Model Evaluation Tool (ESMValTool; Eyring et al., 2016b; Righi et al., 2015). The ESMValTool will run - together with other evaluation tools such as the Program for Climate Model Diagnosis and Intercomparison (PCMDI) metrics package (PMP, Gleckler et al., 2016) - alongside the Earth System Grid Federation (ESGF) as soon as the output is submitted to the CMIP archive so that evaluation results can be made available at a time much faster than in CMIP5 (Eyring et al., 2016c). This will include the evaluation of chemistry and aerosols in the CMIP DECK and CMIP6 historical simulations.

\section{Relations to other MIPs}

AerChemMIP is self-contained in so far as the questions posed can be answered by running only the experiments listed here, the DECK, and historical. For a full analysis of the past and future climate-composition interactions (including unreactive greenhouse gases) in the CMIP6 chemistryclimate models, we recommend that as many as possible of the Tier 1 simulations of RFMIP (Pincus et al., 2016), DAMIP (Gillett et al., 2016), ScenarioMIP (O'Neill et al., 2016), C4MIP (Jones et al., 2016) and LUMIP (Lawrence et al., 2016) are run with the AER CHEM model configuration and with AerChemMIP diagnostics.

\subsection{Radiative Forcing MIP (RFMIP)}

There are considerable synergies between AerChemMIP and RFMIP. RFMIP addresses the ERF due to all drivers for the historical and future periods. AerChemMIP specifically looks to quantify the ERFs for reactive species and aerosols, and to separate individual components of these. RFMIP also contains other components related to the assessment of model radiation code performance and simulations with prescribed aerosol distributions and aerosol optical properties for historical following a similar philosophy to the "Easy Aerosol" project.

For the prescribed SST experiments to diagnose transient ERFs, RFMIP uses the pre-industrial conditions as the reference and perturbs one group of species at a time to evolve following historical (e.g. in piClim-histaerO3); consequently RFMIP specifies a pre-industrial SST and sea ice climatology. AerChemMIP uses the evolving conditions (historical) as the reference with one group of species perturbed back to the pre-industrial conditions (e.g. in histSST-piNTCF); therefore AerChemMIP specifies a time-evolving monthly SST and sea ice distribution taken from a coupled historical experiment. The impacts of different approaches for specifying SSTs and sea ice on the total ERF over the satellite era have been estimated to be small in one climate model (Forster et al., 2016).

For models with interactive chemistry, piClim-NTCF and piClim-aerO3 are identical and only need to be run once. For models without interactive chemistry, RFMIP specifies that piClim-aerO3 uses the present-day tropospheric and stratospheric ozone climatology, whereas AerChemMIP specifies that piClim-NTCF uses the control (pre-industrial) ozone climatology.

\subsection{Detection and Attribution MIP (DAMIP)}

There is some overlap between the AerChemMIP coupled model experiments and those requested in DAMIP. For example, AerChemMIP requires the extra historical runs from DAMIP to increase the ensemble size to at least three members. 
The DAMIP historical experiments use the pre-industrial as the control and have one class of species evolving at a time (e.g. hist-aer parallels historical, but with only aerosol forcing evolving), with all others fixed to pre-industrial levels. In contrast, AerChemMIP uses historical as the control and fixes one class of species at a time to pre-industrial levels (e.g. hist-piAer).

The DAMIP hist-stratO3 run has only stratospheric ozone evolving, using either the prescribed CMIP6 ozone dataset (Hegglin et al., 2017) or ozone output from the previous historical run. In the troposphere ozone is fixed to pre-industrial levels. The equivalent experiment for the models with stratospheric chemistry in AerChemMIP fixes halocarbon concentrations at 1950s levels allowing the model chemistry to generate the difference in ozone compared to historical. DAMIP will use SSP2-4.5 as its future scenario, with ssp245-ghg and ssp245aer as variants, so this does not overlap with the AerChemMIP future experiments.

\subsection{Other MIPs}

The future scenario SSP3-7.0 (experiment ssp370) is prescribed as a Tier 1 scenario in ScenarioMIP with extra ensemble members as Tier 2. A total of three members (using the AerChemMIP model configuration) are required as the baseline for the AerChemMIP future experiments. We recommend that the AER CHEM configuration with AerChemMIP diagnostics be used for as many as possible of the other ScenarioMIP experiments in order to understand the range of possible future evolution of aerosols, reactive gases and surface air quality concentrations.

The future land-use ERF calculations (ssp370SSTssp126Lu) in AerChemMIP (Sect. 3.2.2) parallel the full climate land-use perturbation (ssp370-ssp126Lu) in LUMIP. If the same model configurations are used for both, this will allow direct quantification of the efficacy of land-use changes.

We recommend that the AER CHEM configuration with AerChemMIP diagnostics be used for the C4MIP $1 \% \mathrm{yr}^{-1}$ $\mathrm{CO}_{2} \mathrm{RAD}$ and $\mathrm{BGC}$ experiment in order to explore fully the biogeochemical couplings involving aerosols and reactive gases.

\section{Summary}

Advances in climate model development mean that for CMIP6 a larger set of climate models will include interactive simulation of aerosols than at the time of CMIP5, and many will include interactive chemistry of the troposphere and/or stratosphere. AerChemMIP has therefore been designed to quantify the effects of these NTCFs and reactive WMGHGs on climate and also on atmospheric composition and surface air quality.

A focus is on comparing the climate responses (both global and regional) to the heterogeneous forcing patterns generated by changes in emissions of NTCFs and their precursors over the historical period and in future scenarios. The future scenarios consist of a pair differing only in their levels of ambition in air quality policy. The results from these will provide information on the impacts of air quality policies on climate. The forcings are characterised by the ERFs using model simulations with fixed SSTs and sea ice; the responses are characterised by changes in surface temperature and precipitation (amongst others) using model simulations with coupled oceans.

AerChemMIP will identify the contributions to the present-day climate (in terms of ERF) made by aerosol emissions, tropospheric ozone production, stratospheric ozone depletion, and changes in the reactive gases methane and nitrous oxide.

To add to the forcing-response relationships, AerChemMIP will also provide information on climate feedbacks by calculating the radiative effect of natural emissions of aerosols or ozone precursors in the same way as ERFs of anthropogenic species. Combining these ERFs with diagnosed changes in natural emissions from the DECK $1 \% \mathrm{yr}^{-1} \mathrm{CO}_{2}$ (1pctco2) or $4 \times \mathrm{CO}_{2}$ (abrupt $4 \mathrm{co} 2$ ) simulations would give the climate feedback parameters. AerChemMIP is therefore key to understanding the behaviours of models with aerosols and chemistry in CMIP6, and we would encourage all such models to participate.

\section{Data availability}

The climate model output from AerChemMIP experiments described in this paper will be distributed through the Earth System Grid Federation (ESGF) with DOIs assigned. As in CMIP5, the model output will be freely accessible through data portals after registration. In order to document CMIP6's impact and enable ongoing support of CMIP, users are obligated to acknowledge CMIP6 and the participating modelling groups (see details on the CMIP Panel website at http://www.wcrp-climate.org/index.php/wgcm-cmip/ about-cmip). In order to run the experiments, datasets for natural and anthropogenic forcings are required. These forcing datasets are described in separate invited contributions to this Special Issue. The forcing datasets will be made available through the ESGF (https://pcmdi.llnl.gov/projects/ input4mips/) with version control and DOIs assigned.

\section{The Supplement related to this article is available online at doi:10.5194/gmd-10-585-2017-supplement.}

Competing interests. The authors declare that they have no conflict of interest. 
Acknowledgements. CRESCENDO project members (Bill Collins, Michael Schulz, Olivier Boucher, and Veronika Eyring) acknowledge funding received from the European Union's Horizon 2020 research and innovation programme under grant agreement no. 641816 (CRESCENDO). This work benefitted also from Norwegian research council projects no. 235548 (Role of SLCF in Global Climate Regime) and no. 229796 (AeroCom-P3).

Edited by: F. O'Connor

Reviewed by: two anonymous referees

\section{References}

Arblaster, J. M. and Meehl, G. A.: Contributions of external forcings to southern annular mode trends, J. Clim., 19, 2896-2905, doi:10.1175/JCLI3774.1, 2006.

Archibald, A. T., Cooke, M. C., Utembe, S. R., Shallcross, D. E., Derwent, R. G., and Jenkin, M. E.: Impacts of mechanistic changes on $\mathrm{HO}_{x}$ formation and recycling in the oxidation of isoprene, Atmos. Chem. Phys., 10, 8097-8118, doi:10.5194/acp-108097-2010, 2010.

Arneth, A., Harrison, S. P., Zaehle, S., Tsigaridis, K., Menon, S., Bartlein, P. J., Feichter, J., Korhola, A., Kulmala, M., O’Donnell, D., Schurgers, G., Sorvari, S., and Vesala, T.: Terrestrial biogeochemical feedbacks in the climate system, Nature Geosci., 3, 525-532, 2010.

Banerjee, A., Maycock, A. C., Archibald, A. T., Abraham, N. L., Telford, P., Braesicke, P., and Pyle, J. A.: Drivers of changes in stratospheric and tropospheric ozone between year 2000 and 2100, Atmos. Chem. Phys., 16, 2727-2746, doi:10.5194/acp-162727-2016, 2016.

Bindoff, N. L., Stott, P. A., AchutaRao, K. M., Allen, M. R., Gillett, N., Gutzler, D., Hansingo, K., Hegerl, G., Hu, Y., Jain, S., Mokhov, I. I., Overland, J., Perlwitz, J., Sebbari, R., and Zhang, X.: Detection and Attribution of Climate Change: from Global to Regional, in: Climate Change 2013: The Physical Science Basis. Contribution of Working Group I to the Fifth Assessment Report of the Intergovernmental Panel on Climate Change, edited by: Stocker, T. F., Qin, D., Plattner, G.-K., Tignor, M., Allen, S. K., Boschung, J., Nauels, A., Xia, Y., Bex, V., and Midgley, P. M., Cambridge University Press, Cambridge, United Kingdom and New York, NY, USA, 2013.

Bollasina, M. A., Ming, Y., and Ramaswamy, V.: Earlier onset of the Indian monsoon in the late twentieth century: The role of anthropogenic aerosols, Geophys. Res. Lett., 40, 3715-3720, doi:10.1002/grl.50719, 2013.

Bond, T. C., Doherty, S. J., Fahey, D. W., Forster, P. M., Berntsen, T., DeAngelo, B. J., Flanner, M. G., Ghan, S., Kärcher, B., Koch, D., Kinne, S., Kondo, Y., Quinn, P. K., Sarofim, M. C., Schultz, M. G., Schulz, M., Venkataraman, C., Zhang, H., Zhang, S., Bellouin, N., Guttikunda, S. K., Hopke, P. K., Jacobson, M. Z., Kaiser, J. W., Klimont, Z., Lohmann, U., Schwarz, J. P., Shindell, D., Storelvmo, T., Warren, S. G., and Zender, C. S.: Bounding the role of black carbon in the climate system: A scientific assessment, J. Geophys. Res., 118, 5380-5552, doi:10.1002/jgrd.50171, 2013.

Boucher, O., Randall, D., Artaxo, P., Bretherton, C., Feingold, G., Forster, P., Kerminen, V.-M., Kondo, Y., Liao, H., Lohmann, U.,
Rasch, P., Satheesh, S. K., Sherwood, S., Stevens, B., and Zhang, X. Y.: Clouds and Aerosols, in: Climate Change 2013: The Physical Science Basis. Contribution of Working Group I to the Fifth Assessment Report of the Intergovernmental Panel on Climate Change, edited by: Stocker, T. F., Qin, D., Plattner, G.-K., Tignor, M., Allen, S. K., Boschung, J., Nauels, A., Xia, Y., Bex, V., and Midgley, P. M., 571-657, Cambridge University Press, Cambridge, United Kingdom and New York, NY, USA, 2013.

Cameron-Smith, P., Elliott, S., Maltrud, M., Erickson, D., and Wingenter, O.: Changes in dimethyl sulfide oceanic distribution due to climate change, Geophys. Res. Lett., 38, L07704, doi:10.1029/2011GL047069, 2011.

Carlton, A. G., Pinder, R. W., Bhave, P. V., and Pouliot, G. A.: To what extent can biogenic SOA be controlled?, Environ. Sci. Technol., 44, 3376-3380, doi:10.1021/es903506b, 2010.

Carslaw, K. S., Lee, L. A., Reddington, C. L., Pringle, K. J., Rap, A., Forster, P. M., Mann, G. W., Spracklen, D. V., Woodhouse, M. T., Regayre, L. A., and Pierce, J. R.: Large contribution of natural aerosols to uncertainty in indirect forcing, Nature, 503, 7474, doi:10.1038/nature12674, 2013.

Clarke, L., Jiang, K., Akimoto, K., Babiker, M., Blanford, G., Fisher-Vanden, K., Hourcade, J.-C., Krey, V., Kriegler, E., Löschel, A., McCollum, D., Paltsev, S., Rose, S., Shukla, P. R., Tavoni, M., van der Zwaan, B. C. C., and van Vuuren, D. P.: Assessing Transformation Pathways, in: Climate Change 2014: Mitigation of Climate Change. Contribution of Working Group III to the Fifth Assessment Report of the Intergovernmental Panel on Climate Change, edited by: Edenhofer, O., Pichs-Madruga, R., Sokona, Y., Farahani, E., Kadner, S., Seyboth, K., Adler, A., Baum, I., Brunner, S., Eickemeier, P., Kriemann, B., Savolainen, J., Schlömer, S., von Stechow, C., Zwickel, T., and Minx, J. C., Cambridge University Press, Cambridge, United Kingdom and New York, NY, USA, 2014.

Collins, W. J., Derwent, R. G., Garnier, B., Johnson, C. E., Sanderson, M. G., and Stevenson, D. S.: The effect of stratospheretroposphere exchange on the future tropospheric ozone trend, J. Geophys. Res., 108, 8253, doi:10.1029/2002JD002617, 2003.

Collins, W. J., Bellouin, N., Doutriaux-Boucher, M., Gedney, N., Halloran, P., Hinton, T., Hughes, J., Jones, C. D., Joshi, M., Liddicoat, S., Martin, G., O'Connor, F., Rae, J., Senior, C., Sitch, S., Totterdell, I., Wiltshire, A., and Woodward, S.: Development and evaluation of an Earth-System model - HadGEM2, Geosci. Model Dev., 4, 1051-1075, doi:10.5194/gmd-4-10512011, 2011.

Collins, M. R., Knutti, R., Arblaster, J., Dufresne, J.-L., Fichefet, T., Friedlingstein, P., Gao, X., Gutowski, W. J., Johns, T., Krinner, G., Shongwe, M., Tebaldi, C., Weaver, A. J., and Wehner, M.: Long-term Climate Change: Projections, Commitments and Irreversibility, in: Climate Change 2013: The Physical Science Basis. Contribution of Working Group I to the Fifth Assessment Report of the Intergovernmental Panel on Climate Change, edited by: Stocker, T. F., Qin, D., Plattner, G.-K., Tignor, M., Allen, S. K., Boschung, J., Nauels, A., Xia, Y., Bex, V., and Midgley, P. M., Cambridge University Press, Cambridge, United Kingdom and New York, NY, USA, 2013.

Eyring, V., Waugh, D., Bodeker, G., Cordero, E., Akiyoshi, H., Austin, J., Beagley, S., Boville, B., Braesicke, P., Bruhl, C., Butchart, N., Chipperfield, M., Dameris, M., Deckert, R., Deushi, M., Frith, S., Garcia, R., Gettelman, A., Giorgetta, M., Kinni- 
son, D., Mancini, E., Manzini, E., Marsh, D., Matthes, S., Nagashima, T., Newman, P., Nielsen, J., Pawson, S., Pitari, G., Plummer, D., Rozanov, E., Schraner, M., Scinocca, J., Semeniuk, K., Shepherd, T., Shibata, K., Steil, B., Stolarski, R., Tian, W., and Yoshiki, M.: Multimodel projections of stratospheric ozone in the 21 st century, J. Geophys. Res.-Atmos., 112, D16303, doi:10.1029/2006JD008332, 2007.

Eyring, V., Lamarque, J.-F., Hess, P., Arfeuille, F., Bowman, K., Chipperfield, M. P., Duncan, B., Fiore, A., Gettelman, A., Giorgetta, M. A., Granier, C., Hegglin, M., Kinnison, D., Kunze, M., Langematz, U., Luo, B., Martin, R., Matthes, K., Newman, P. A., Peter, T., Robock, A., Ryerson, T., Saiz-Lopez, A., Salawitch, R., Schultz, M., Shepherd, T. G., Shindell, D., Staehelin, J., Tegtmeier, S., Thomason, L., Tilmes, S., Vernier, J.-P., Waugh, D. W., and Young, P. J.: Overview of IGAC/SPARC Chemistry-Climate Model Initiative (CCMI) Community Simulations in Support of Upcoming Ozone and Climate Assessments, SPARC Newsletter, 40, 48-66, 2013a.

Eyring, V., Arblaster, J. M., Cionni, I., Sedlacek, J., Perlwitz, J., Young, P. J., Bekki, S., Bergmann, D., Cameron-Smith, P., Collins, W. J., Faluvegi, G., Gottschaldt, K.-D., Horowitz, L. W., Kinnison, D. E., Lamarque, J.-F., Marsh, D. R., Saint-Martin, D., Shindell, D. T., Sudo, K., Szopa, S., and Watanabe, S.: Longterm ozone changes and associated climate impacts in CMIP5 simulations, J. Geophys. Res.-Atmos, 118, 5029-5060, $2013 \mathrm{~b}$.

Eyring, V., Bony, S., Meehl, G. A., Senior, C. A., Stevens, B., Stouffer, R. J., and Taylor, K. E.: Overview of the Coupled Model Intercomparison Project Phase 6 (CMIP6) experimental design and organization, Geosci. Model Dev., 9, 1937-1958, doi:10.5194/gmd-9-1937-2016, 2016a.

Eyring, V., Righi, M., Lauer, A., Evaldsson, M., Wenzel, S., Jones, C., Anav, A., Andrews, O., Cionni, I., Davin, E. L., Deser, C., Ehbrecht, C., Friedlingstein, P., Gleckler, P., Gottschaldt, K.-D., Hagemann, S., Juckes, M., Kindermann, S., Krasting, J., Kunert, D., Levine, R., Loew, A., Mäkelä, J., Martin, G., Mason, E., Phillips, A. S., Read, S., Rio, C., Roehrig, R., Senftleben, D., Sterl, A., van Ulft, L. H., Walton, J., Wang, S., and Williams, K. D.: ESMValTool (v1.0) - a community diagnostic and performance metrics tool for routine evaluation of Earth system models in CMIP, Geosci. Model Dev., 9, 1747-1802, doi:10.5194/gmd9-1747-2016, 2016b.

Eyring, V., Gleckler, P. J., Heinze, C., Stouffer, R. J., Taylor, K. E., Balaji, V., Guilyardi, E., Joussaume, S., Kindermann, S., Lawrence, B. N., Meehl, G. A., Righi, M., and Williams, D. N.: Towards improved and more routine Earth system model evaluation in CMIP, Earth Syst. Dynam., 7, 813-830, doi:10.5194/esd7-813-2016, 2016c.

Ferraro, R., Waliser, D. E., Gleckler, P., Taylor, K. E., and Eyring, V.: Evolving obs4MIPs to Support the Sixth Coupled Model Intercomparison Project (CMIP6), B. Am. Meteorol. Soc., 96, 131-133, doi:10.1175/BAMS-D-14-00216.1, 2015.

Fiore, A. M., Naik, V., Spracklen, D., Steiner, A., Unger, N., Prather, M., Bergmann, D., Cameron-Smith, P. J., Collins, W., Dalsøren, S., Folberth G., Ginoux, P., Horowitz, L. W., Josse, B., Lamarque, J.-F., Nagashima, T., O'Connor, F., Rumbold, S., Shindell, D. T., Skeie, R. B., Sudo, K., Takemura, T., and Zeng, G.: Global Air Quality and Climate, Chem. Soc. Rev., 41, 66636683, doi:10.1039/C2CS35095E, 2012.
Fiore, A. M., Naik, V., and Leibensperger, E. M.: Air quality and climate connections, J. Air Waste Manag. Assoc., 65, 645-685, doi:10.1080/10962247.2015.1040526, 2015.

Flato, G., Marotzke, J., Abiodun, B., Braconnot, P., Chou, S. C., Collins, W., Cox, P., Driouech, F., Emori, S., Eyring, V., Forest, C., Gleckler, P., Guilyardi, E., Jakob, C., Kattsov, V., Reason, C., and Rummukainen, M: Evaluation of Climate Models, in: Climate Change 2013: The Physical Science Basis. Contribution of Working Group I to the Fifth Assessment Report of the Intergovernmental Panel on Climate Change, edited by: Stocker, T. F., Qin, D., Plattner, G.-K., Tignor, M., Allen, S. K., Boschung, J., Nauels, A., Xia, Y., Bex, V., and Midgley, P. M., Cambridge University Press, Cambridge, United Kingdom and New York, NY, USA, 2013.

Forster, P., Ramaswamy, V., Artaxo, P., Berntsen, T., Betts, R., Fahey, D. W., Haywood, J., Lean, J., Lowe, D. C., Myhre, G., Nganga, J., Prinn, R., Raga, G., Schulz, M., and Van Dorland, R.: Changes in Atmospheric Constituents and in Radiative Forcing, in: Climate Change 2007: The Physical Science Basis. Contribution of Working Group I to the Fourth Assessment Report of the Intergovernmental Panel on Climate Change, edited by: Solomon, S., Qin, D., Manning, M., Chen, Z., Marquis, M., Averyt, K. B., Tignor, M., and Miller, H. L., Cambridge University Press, Cambridge, United Kingdom and New York, NY, USA, 129-234, 2007.

Forster, P. M., Richardson, T., Maycock, A. C., Smith, C. J., Samset, B. H., Myhre, G., Andrews, T., Pincus, R., and Schulz, M.: Recommendations for diagnosing effective radiative forcing from climate models for CMIP6, J. Geophys. Res.-Atmos., 121, 12460-12475, doi:10.1002/2016JD025320, 2016.

Fujimori, S., Hasegawa, T., Masuia, T., Takahashia, K., Herran, D. S., Dai, H., Hijioka, Y., and Kainuma, M.: SSP3: AIM implementation of Shared Socioeconomic Pathways, Global Environmental Change, 42, 268-283, doi:10.1016/j.gloenvcha.2016.06.009, 2017.

Gauss, M., Myhre, G., Pitari, G., Prather, M., Isaksen, I., Berntsen, T., Brasseur, G., Dentener, F., Derwent, R., Hauglustaine, D., Horowitz, L., Jacob, D., Johnson, M., Law, K., Mickley, L., Muller, J., Plantevin, P., Pyle, J., Rogers, H., Stevenson, D., Sundet, J., van Weele, M., and Wild, O.: Radiative forcing in the 21 st century due to ozone changes in the troposphere and lower stratosphere, J. Geophys. Res., 108, 4292, doi:10.1029/2002JD002624, 2003.

Gauss, M., Myhre, G., Isaksen, I. S. A., Grewe, V., Pitari, G., Wild, O., Collins, W. J., Dentener, F. J., Ellingsen, K., Gohar, L. K., Hauglustaine, D. A., Iachetti, D., Lamarque, F., Mancini, E., Mickley, L. J., Prather, M. J., Pyle, J. A., Sanderson, M. G., Shine, K. P., Stevenson, D. S., Sudo, K., Szopa, S., and Zeng, G.: Radiative forcing since preindustrial times due to ozone change in the troposphere and the lower stratosphere, Atmos. Chem. Phys., 6, 575-599, doi:10.5194/acp-6-575-2006, 2006.

Ghan, S. J., Liu, X., Easter, R. C., Zaveri, R., Rasch, P. J., Yoon, J.H., and Eaton, B.: Toward a minimal representation of aerosols in climate models: Comparative decomposition of aerosol direct, semi-direct and indirect radiative forcing, J. Clim., 25, 64616476, doi:10.1175/JCLI-D-11-00650.1, 2012.

Ghan, S., Wang, M., Zhang, S., Ferrachat, S., Gettelman, A., Griesfeller, J., Kipling, Z., Lohmann, U., Morrison, H., Neubauer, D., Partridge, D. G., Stier, P., Takemura, T., Wang, H., and 
Zhang, K.: Challenges in constraining anthropogenic aerosol effects on cloud radiative forcing using present-day spatiotemporal variability, P. Natl. Acad. Sci., 113, 5804-5811, doi:10.1073/pnas.1514036113, 2016.

Gillett, N. P., Shiogama, H., Funke, B., Hegerl, G., Knutti, R., Matthes, K., Santer, B. D., Stone, D., and Tebaldi, C.: The Detection and Attribution Model Intercomparison Project (DAMIP v1.0) contribution to CMIP6, Geosci. Model Dev., 9, 3685-3697, doi:10.5194/gmd-9-3685-2016, 2016.

Gleckler, P. J., Doutriaux, C., Durack, P. J., Taylor, K. E., Zhang, Y., Williams, D. N., Mason, E., and Servonnat, J.: A more powerful reality test for climate models, Eos Trans. AGU, 97, 2016.

Gordon, H., Sengupta, K., Rap, A., Duplissy, J., Frege, C., Williamson, C., Heinritzi, M., Simon, M., Yan, C., Almeida, J., Tröstl, J., Nieminen, T., Ortega, I. K., Wagner, R., Dunne, E. M., Adamov, A., Amorim, A., Bernhammer, A.-K., Bianchi, F., Breitenlechner, M., Brilke, S., Chen, X., Craven, J. S., Dias, A., Ehrhart, S., Fischer, L., Flagan, R. C., Franchin, A., Fuchs, C., Guida, R., Hakala, J., Hoyle, C. R., Jokinen, T., Junninen, H., Kangasluoma, J., Kim, J., Kirkby, J., Krapf, M., Kürten, A., Laaksonen, A., Lehtipalo, K., Makhmutov, V., Mathot, S., Molteni, U., Monks, S. A., Onnela, A., Peräkylä, O., Piel, F., Petäjä, T., Praplan, A. P., Pringle, K. J., Richards, N. A. D., Rissanen, M. P., Rondo, L., Sarnela, N., Schobesberger, S., Scott, C. E., Seinfeld, J. H., Sharma, S., Sipilä, M., Steiner, G., Stozhkov, Y., Stratmann, F., Tomé, A., Virtanen, A., Vogel, A. L., Wagner, A. C., Wagner, P. E., Weingartner, E., Wimmer, D., Winkler, P. M., Ye, P., Zhang, X., Hansel, A., Dommen, J., Donahue, N. M., Worsnop, D. R., Baltensperger, U., Kulmala, M., Curtius, J., and Carslaw, K. S.: Reduced anthropogenic aerosol radiative forcing caused by biogenic new particle formation, P. Natl. Acad. Sci., 113, 12053-12058, doi:10.1073/pnas.1602360113, 2016.

Granier, C., Bessagnet, B., Bond, T., D’Angiola, A., Denier van der Gon, H., Frost, G. J., Heil, A., Kaiser, J. W., Kinne, S., Klimont, Z., Kloster, S., Lamarque, J.-F., Liousse, C., Masui, T., Meleux, F., Mieville, A., Ohara, T., Raut, J.-C., Riahi, K., Schultz, M. G., Smith, S. J., Thompson, A., van Aardenne, J., van der Werf, G. R., and van Vuuren, D. P.: Evolution of anthropogenic and biomass burning emissions of air pollutants at global and regional scales during the 1980-2010 period, Climatic Change, 109, 163-190, doi:10.1007/s10584-011-0154-1, 2011.

Hegglin, M. I. and Shepherd, T. G.: Large climate-induced changes in ultraviolet index and stratosphere-to-troposphere ozone flux, Nature Geosci., 2, 687-691, 2009.

Hegglin, M. I., Tegtmeier, S., Anderson, J., Bourassa, A., Brohede, S., Degenstein, D., Froidevaux, L., Funke, B., Gille, J., Jones, A., Kasai, Y., Kyro, E., Lumpe, J., Neu, J., Remsberg, E., Rozanov, A., Toohey, M., Urban, J., von Clarmann, T., Walker, K. A., Wang, R., Fuller, R., Lingenfelser, G., McLinden, C., Nardi, B., Roth, C., Smith, L., and Pendlebury, D.: SPARC Data Initiative: Comparison of stratospheric composition measurements from international satellite limb sounders, in preparation, 2017.

Hoesly, R. M., Smith, S. ., Feng, L., Klimont, Z., JanssensMaenhout, G., Pitkanen, T., Seibert, J. J., Vu, L., Andres, R. J., Bolt, R. M., Bond, T. C., Dawidowski, L., Kholod, N., Kurokawa, J., Li, M., Liu, L., Lu, Z., Moura, M. C. P., O’Rourke, R. R., and Zhang Q.: Historical (1750-2014) anthropogenic emissions of reactive gases and aerosols from the Community Emission Data System (CEDS), in preparation, 2017.
Hollmann, R., Merchant, C. J., Saunders, R., Downy, C., Buchwitz, M., Cazenave, A., Chuvieco, E., Defourny, P., de Leeuw, G., Forsberg, R., Holzer-Popp, T., Paul, F., Sandven, S., Sathyendranath, S., van Roozendael, M., and Wagner, W.: The ESA Climate Change Initiative: Satellite Data Records for Essential Climate Variables, B. Am. Meteor. Soc., 94, 15411552, doi:10.1175/BAMS-D-11-00254.1, 2013.

Hwang, Y. T., Frierson, D. M., and Kang, S. M.: Anthropogenic sulfate aerosol and the southward shift of tropical precipitation in the late 20th century, Geophys. Res. Lett., 40, 2845-2850, doi: $10.1002 /$ grl.50502, 2013.

IPCC: Climate Change 1994: Radiative Forcing of Climate Change and an Evaluation of the IPCC IS92 Emission, edited by: Houghton, J. T., Meira Filho, L. G., Bruce, J., Lee, H., Callander, B. A., Haites, E., Harris, N., and Maskell, K., Cambridge University Press, Cambridge, UK, 339 pp., 1994.

IPCC: Climate Change 1995: The Science of Climate Change. Contribution of Working Group I to the Second Assessment Report of the Intergovernmental Panel on Climate Change, edited by: Houghton, J. T., Meira Filho, L. G., Callander, B. A., Harris, N., Kattenberg, A., and Maskell, K., Cambridge University Press, Cambridge, United Kingdom and New York, NY, USA, 572 pp., 1996.

Isaksen, I. S. A., Granier, C., Myhre, G., Berntsen, T. K., Dalsøren, S. B., Gauss, M., Klimont, Z., Benestad, R., Bousquet, P., and Collins, W.: Atmospheric composition change: climatechemistry interactions, Atmos. Environ., 4, 5138-5192, 2009.

Jacob, D. J. and Winner, D. A.: Effect of climate change on air quality, Atmos. Environ., 43, 51-63, doi:10.1016/j.atmosenv.2008.09.051, 2009.

John, J. G., Fiore, A. M., Naik, V., Horowitz, L. W., and Dunne, J. P.: Climate versus emission drivers of methane lifetime against loss by tropospheric OH from 1860-2100, Atmos. Chem. Phys., 12, 12021-12036, doi:10.5194/acp-12-12021-2012, 2012.

Jones, C. D., Arora, V., Friedlingstein, P., Bopp, L., Brovkin, V., Dunne, J., Graven, H., Hoffman, F., Ilyina, T., John, J. G., Jung, M., Kawamiya, M., Koven, C., Pongratz, J., Raddatz, T., Randerson, J. T., and Zaehle, S.: C4MIP - The Coupled Climate-Carbon Cycle Model Intercomparison Project: experimental protocol for CMIP6, Geosci. Model Dev., 9, 2853-2880, doi:10.5194/gmd-92853-2016, 2016.

Kinne, S., Schulz, M., Textor, C., Guibert, S., Balkanski, Y., Bauer, S. E., Berntsen, T., Berglen, T. F., Boucher, O., Chin, M., Collins, W., Dentener, F., Diehl, T., Easter, R., Feichter, J., Fillmore, D., Ghan, S., Ginoux, P., Gong, S., Grini, A., Hendricks, J., Herzog, M., Horowitz, L., Isaksen, I., Iversen, T., Kirkevåg, A., Kloster, S., Koch, D., Kristjansson, J. E., Krol, M., Lauer, A., Lamarque, J. F., Lesins, G., Liu, X., Lohmann, U., Montanaro, V., Myhre, G., Penner, J., Pitari, G., Reddy, S., Seland, O., Stier, P., Takemura, T., and Tie, X.: An AeroCom initial assessment - optical properties in aerosol component modules of global models, Atmos. Chem. Phys., 6, 1815-1834, doi:10.5194/acp-6-1815-2006, 2006.

Kirtman, B., Power, S. B., Adedoyin, J. A., Boer, G. J., Bojariu, R., Camilloni, I., Doblas-Reyes, F. J., Fiore, A. M., Kimoto, M., Meehl, G. A., Prather, M., Sarr, A., Schär, C., Sutton, R., van Oldenborgh, G. J., Vecchi, G., and Wang, H. J.: Near-term Climate Change: Projections and Predictability, in: Climate Change 2013: The Physical Science Basis. Contribution of Working 
Group I to the Fifth Assessment Report of the Intergovernmental Panel on Climate Change, edited by: Stocker, T. F., Qin, D., Plattner, G.-K., Tignor, M., Allen, S. K., Boschung, J., Nauels, A., Xia, Y., Bex, V., and Midgley, P. M., Cambridge University Press, Cambridge, United Kingdom and New York, NY, USA, 2013.

Lamarque, J.-F., Shindell, D. T., Josse, B., Young, P. J., Cionni, I., Eyring, V., Bergmann, D., Cameron-Smith, P., Collins, W. J., Doherty, R., Dalsoren, S., Faluvegi, G., Folberth, G., Ghan, S. J., Horowitz, L. W., Lee, Y. H., MacKenzie, I. A., Nagashima, T., Naik, V., Plummer, D., Righi, M., Rumbold, S. T., Schulz, M., Skeie, R. B., Stevenson, D. S., Strode, S., Sudo, K., Szopa, S., Voulgarakis, A., and Zeng, G.: The Atmospheric Chemistry and Climate Model Intercomparison Project (ACCMIP): overview and description of models, simulations and climate diagnostics, Geosci. Model Dev., 6, 179-206, doi:10.5194/gmd-6-179-2013, 2013.

Langner, J. and Rodhe, H.: A global three-dimensional model of the tropospheric sulphur cycle, J. Atmos. Chem., 13, 255-263, 1991.

Lawrence, D. M., Hurtt, G. C., Arneth, A., Brovkin, V., Calvin, K. V., Jones, A. D., Jones, C. D., Lawrence, P. J., de NobletDucoudré, N., Pongratz, J., Seneviratne, S. I., and Shevliakova, E.: The Land Use Model Intercomparison Project (LUMIP) contribution to CMIP6: rationale and experimental design, Geosci. Model Dev., 9, 2973-2998, doi:10.5194/gmd-9-29732016, 2016.

Leibensperger, E. M., Mickley, L. J., Jacob, D. J., Chen, W.-T., Seinfeld, J. H., Nenes, A., Adams, P. J., Streets, D. G., Kumar, N., and Rind, D.: Climatic effects of 1950-2050 changes in US anthropogenic aerosols - Part 2: Climate response, Atmos. Chem. Phys., 12, 3349-3362, doi:10.5194/acp-12-3349-2012, 2012.

Levy, H., Horowitz, L. W., Schwarzkopf, M. D., Ming, Y., Golaz, J.-C., Naik, V., and Ramaswamy, V.: The roles of aerosol direct and indirect effects in past and future climate change, J. Geophys. Res.-Atmos., 118, 4521-4532, doi:10.1002/jgrd.50192, 2013.

Marvel, K., Schmidt, G. A., Miller, R. L., and Nazarenko, L. S.: Implications for climate sensitivity from the response to individual forcings, Nature Climate Change, 6, 386-389, doi:10.1038/nclimate2888, 2016.

McCoy, D. T., Burrows, S. M., Wood, R., Grosvenor, D. P., Elliott, S. M., Ma, P.-L., Rasch, P. J., and Hartmann, D. L.: Natural aerosols explain seasonal and spatial patterns of Southern Ocean cloud albedo, Sci. Adv., 1, e1500157, doi:10.1126/sciadv.1500157, 2015.

McLandress, C., Shepherd, T. G., Scinocca, J. F., Plummer, D. A., Sigmond, M., Jonsson, A. I., and Reader, M. C.: Separating the dynamical effects of climate change and ozone depletion. Part II Southern Hemisphere troposphere, J. Clim., 24, 1850-1868, 2011.

McLandress, C., Shepherd, T. G., Jonsson, A. I., von Clarmann, T., and Funke, B.: A method for merging nadir-sounding climate records, with an application to the global-mean stratospheric temperature data sets from SSU and AMSU, Atmos. Chem. Phys., 15, 9271-9284, doi:10.5194/acp-15-9271-2015, 2015.

Morgenstern, O., Hegglin, M. I., Rozanov, E., O’Connor, F. M., Abraham, N. L., Akiyoshi, H., Archibald, A. T., Bekki, S., Butchart, N., Chipperfield, M. P., Deushi, M., Dhomse, S. S., Garcia, R. R., Hardiman, S. C., Horowitz, L. W., Jöckel, P., Josse, B., Kinnison, D., Lin, M., Mancini, E., Manyin, M. E.,
Marchand, M., Marécal, V., Michou, M., Oman, L. D., Pitari, G., Plummer, D. A., Revell, L. E., Saint-Martin, D., Schofield, R., Stenke, A., Stone, K., Sudo, K., Tanaka, T. Y., Tilmes, S., Yamashita, Y., Yoshida, K., and Zeng, G.: Review of the global models used within the Chemistry-Climate Model Initiative (CCMI), Geosci. Model Dev. Discuss., doi:10.5194/gmd2016-199, in review, 2016.

Myhre, G., Shindell, D., Bréon, F.-M., Collins, W., Fuglestvedt, J., Huang, J., Koch, D., Lamarque, J.-F., Lee, D., Mendoza, B., Nakajima, T., Robock, A., Stephens, G., Takemura, T., and Zhang, H.: Anthropogenic and Natural Radiative Forcing, in: Climate Change 2013: The Physical Science Basis. Contribution of Working Group I to the Fifth Assessment Report of the Intergovernmental Panel on Climate Change, edited by: Stocker, T. F., Qin, D., Plattner, G.-K., Tignor, M., Allen, S. K., Boschung, J., Nauels, A., Xia, Y., Bex, V., and Midgley, P. M., 659-740, Cambridge University Press, Cambridge, United Kingdom and New York, NY, USA, 2013a.

Myhre, G., Samset, B. H., Schulz, M., Balkanski, Y., Bauer, S., Berntsen, T. K., Bian, H., Bellouin, N., Chin, M., Diehl, T., Easter, R. C., Feichter, J., Ghan, S. J., Hauglustaine, D., Iversen, T., Kinne, S., Kirkevåg, A., Lamarque, J.-F., Lin, G., Liu, X., Lund, M. T., Luo, G., Ma, X., van Noije, T., Penner, J. E., Rasch, P. J., Ruiz, A., Seland, Ø., Skeie, R. B., Stier, P., Takemura, T., Tsigaridis, K., Wang, P., Wang, Z., Xu, L., Yu, H., Yu, F., Yoon, J.-H., Zhang, K., Zhang, H., and Zhou, C.: Radiative forcing of the direct aerosol effect from AeroCom Phase II simulations, Atmos. Chem. Phys., 13, 1853-1877, doi:10.5194/acp-13-18532013, 2013b.

Naik, V., Voulgarakis, A., Fiore, A. M., Horowitz, L. W., Lamarque, J.-F., Lin, M., Prather, M. J., Young, P. J., Bergmann, D., Cameron-Smith, P. J., Cionni, I., Collins, W. J., Dalsøren, S. B., Doherty, R., Eyring, V., Faluvegi, G., Folberth, G. A., Josse, B., Lee, Y. H., MacKenzie, I. A., Nagashima, T., van Noije, T. P. C., Plummer, D. A., Righi, M., Rumbold, S. T., Skeie, R., Shindell, D. T., Stevenson, D. S., Strode, S., Sudo, K., Szopa, S., and Zeng, G.: Preindustrial to present-day changes in tropospheric hydroxyl radical and methane lifetime from the Atmospheric Chemistry and Climate Model Intercomparison Project (ACCMIP), Atmos. Chem. Phys., 13, 5277-5298, doi:10.5194/acp-13-5277-2013, 2013.

Olson, J., Prather, M., Berntsen, T., Carmichael, G., Chatfield, R., Connell, P., Derwent, R., Horowitz, L., Jin, S., Kanakidou, M., Kasibhatla, P., Kotamarthi, R., Kuhn, M., Law, K., Penner, J., Perliski, L., Sillman, S., Stordal, F., Thompson, A., and Wild, O.: Results from the Intergovernmental Panel on Climatic Change Photochemical Model Intercomparison (PhotoComp), J. Geophys. Res., 102, 5979-5991, 1997.

O’Neill, B. C., Kriegler, E., Riahi, K., Ebi, K. L., Hallegatte, S., Carter, T. R., Mathur, R., and Van Vuuren, D. P.: A new scenario framework for climate change research: The concept of shared socioeconomic pathways, Clim. Change, 122, 387-400, 2014.

O’Neill, B. C., Tebaldi, C., van Vuuren, D. P., Eyring, V., Friedlingstein, P., Hurtt, G., Knutti, R., Kriegler, E., Lamarque, J.-F., Lowe, J., Meehl, G. A., Moss, R., Riahi, K., and Sanderson, B. M.: The Scenario Model Intercomparison Project (ScenarioMIP) for CMIP6, Geosci. Model Dev., 9, 3461-3482, doi:10.5194/gmd-9-3461-2016, 2016. 
Pawson, S. and Steinbrecht, W. (Lead Authors), Charlton-Perez, A. J., Fujiwara, M., Karpechko, A. Yu., Petropavlovskikh, I., Urban, J., and Weber, M.: Update on global ozone: Past, present, and future, Chapter 2 in Scientific Assessment of Ozone Depletion: 2014, Global Ozone Research and Monitoring Project - Report No. 55, World Meteorological Organization, Geneva, Switzerland, 2014.

Penner, J. E., Andreae, M., Annegarn, H., Barrie, L., Feichter, J., Hegg, D., Jayaraman, A., Leaitch, R., Murphy, D., Nganga, J., and Pitari, G.: Aerosols, their direct and indirect effects, in: Climate Change 2001: The Scientific Basis. Contribution of Working Group I to the Third Assessment Report of the Intergovernmental Panel on Climate Change, edited by: Houghton, J. T., Ding, Y., Griggs, D. J., Noguer, M., van der Linden, P. J., Dai, X., Maskell, K., and Johnson, C. A., Cambridge University Press, Cambridge, United Kingdom and New York, NY, USA, 289-348, 2001.

Pincus, R., Forster, P. M., and Stevens, B.: The Radiative Forcing Model Intercomparison Project (RFMIP): experimental protocol for CMIP6, Geosci. Model Dev., 9, 3447-3460, doi:10.5194/gmd-9-3447-2016, 2016.

Polvani, L. M., Waugh, D. W., Correa, G. J. P., and Son, S. W.: Stratospheric ozone depletion: The main driver of twentiethcentury atmospheric circulation changes in the Southern Hemisphere, J. Clim., 24, 795-812, 2011.

Prather, M. J.: Lifetimes and eigenstates in atmospheric chemistry, Geophys. Res. Lett., 21, 801-804, 1994.

Prather, M., Derwent, R., Ehhalt, D., Fraser, P., Sanhueza, E., and Zhou, X.: Chapter 2: Other tracer gases and atmospheric chemistry, in: Climate Change 1994, Intergovernmental Panel on Climate Change, edited by: Houghton, J. T., Ding, Y., Griggs, D. J., Noguer, M., van der Linden, P. J., Dai, X., Maskell, K., and Johnson, C. A., Cambridge U. Press, 73-126, 1994.

Prather, M., Ehhalt, D., Dentener, F., Derwent, R., Dlugokencky, E., Holland, E., Isaksen, Katima, J., Kirchhoff, V., Matson, P., Midgley, P., and Wang, M.: Atmospheric Chemistry and Greenhouse Gases, in: Climate Change 2001: The Scientific Basis, edited by: Houghton, J. T., Ding, Y., Griggs, D. J., Noguer, M., van der Linden, P. J., Dai, X., Maskell, K., and Johnson, C. A., Cambridge University Press, Cambridge, UK, 239-287, 2001.

Ramaswamy, V., Boucher, O., Haigh, J., Hauglustaine, D., Haywood, J., Myhre, G., Nakajima, T., Shi, G. Y., and Solomon, S.: Radiative forcing of climate change, in: Climate Change 2001: The Scientific Basis. Contribution of Working Group I to the Third Assessment Report of the Intergovernmental Panel on Climate Change, edited by: Houghton, J. T., Ding, Y., Griggs, D. J., Noguer, M., van der Linden, P. J., Dai, X., Maskell, K., and Johnson, C. A., Cambridge University Press, Cambridge, United Kingdom and New York, NY, USA, 349-416, 2001.

Rao, S., Klimont, Z., Smith, S. J., Van Dingenen, R., Dentener, F., Bouwman, L., Riahi, K., Amann, M., Bodirsky, B. L., van Vuuren, D. P., Reis, L. A., Calvin, K., Drouet, L., Fricko, O., Fujimori, S., Gernaat, D., Havlik, P., Harmsen, M., Hasegawa, T., Heyes, C., Hilaire, J., Luderer, G., Masui, G., Stehfest, E., Strefler, J., van der Sluis, S., and Tavoni, M.: Future air pollution in the Shared Socio-economic Pathways, Global Environmental Change, 42, 346-358, doi:10.1016/j.gloenvcha.2016.05.012, 2017.
Righi, M., Eyring, V., Gottschaldt, K.-D., Klinger, C., Frank, F., Jöckel, P., and Cionni, I.: Quantitative evaluation of ozone and selected climate parameters in a set of EMAC simulations, Geosci. Model Dev., 8, 733-768, doi:10.5194/gmd-8-733-2015, 2015.

Rotstayn, L., Collier, M., Shindell, D., and Boucher, O.: Why does aerosol forcing control historical global-mean surface temperature change in CMIP5 models?, J. Climate, 28, 6608-6625, 2015.

Schnell, J. L., Prather, M. J., Josse, B., Naik, V., Horowitz, L. W., Cameron-Smith, P., Bergmann, D., Zeng, G., Plummer, D. A., Sudo, K., Nagashima, T., Shindell, D. T., Faluvegi, G., and Strode, S. A.: Use of North American and European air quality networks to evaluate global chemistry-climate modeling of surface ozone, Atmos. Chem. Phys., 15, 10581-10596, doi:10.5194/acp-15-10581-2015, 2015.

Schnell, J. L., Prather, M. J., Josse, B., Naik, V., Horowitz, L. W., Zeng, G., and Shindell, D. T.: Effect of climate change on surface ozone over North America, Europe, and East Asia, Geophys. Res. Lett., 43, 3509-3518, 2016.

Schulz, M., Textor, C., Kinne, S., Balkanski, Y., Bauer, S., Berntsen, T., Berglen, T., Boucher, O., Dentener, F., Guibert, S., Isaksen, I. S. A., Iversen, T., Koch, D., Kirkevåg, A., Liu, X., Montanaro, V., Myhre, G., Penner, J. E., Pitari, G., Reddy, S., Seland, $\varnothing$., Stier, P., and Takemura, T.: Radiative forcing by aerosols as derived from the AeroCom present-day and pre-industrial simulations, Atmos. Chem. Phys., 6, 5225-5246, doi:10.5194/acp-65225-2006, 2006.

Sherwood, S., Bony, S., Boucher, O., Bretherton, C., Forster, P., Gregory, J., and Stevens, B.: Adjustments to the forcing-feedback framework for understanding climate change, B. Am. Meteorol. Soc., 96, 217-228, 2015.

Shindell, D. T.: Inhomogeneous forcing and transient climate sensitivity, Nature Climate Change, 4, 274-277, doi:10.1038/nclimate2136, 2014.

Shindell, D. T., Faluvegi, G., Koch, D. M., Schmidt, G. A., Unger, N., and Bauer, S. E.: Improved Attribution of Climate Forcing to Emissions, Science, 326, 716-718, 2009.

Shindell, D., Kuylenstierna, J., Vignati, E., van Dingenen, R., Amann, M., Klimont, Z., Anenberg, S., Muller, N., JanssensMaenhout, G., Raes, F., Schwartz, J., Faluvegi, G., Pozzoli, L., Kupiainen, K., Hoglund-Isaksson, L., Emberson, L., Streets, D., Ramanathan, V., Hicks, K., Oanh, N., Milly, G., Williams, M., Demkine, V., and Fowler, D.: Simultaneously mitigating nearterm climate change and improving human health and food security, Science, 335, 183-189, 2012a.

Shindell, D. T., Voulgarakis, A., Faluvegi, G., and Milly, G.: Precipitation response to regional radiative forcing, Atmos. Chem. Phys., 12, 6969-6982, doi:10.5194/acp-12-6969-2012, 2012 b.

Shindell, D. T., Lamarque, J.-F., Schulz, M., Flanner, M., Jiao, C., Chin, M., Young, P. J., Lee, Y. H., Rotstayn, L., Mahowald, N., Milly, G., Faluvegi, G., Balkanski, Y., Collins, W. J., Conley, A. J., Dalsoren, S., Easter, R., Ghan, S., Horowitz, L., Liu, X., Myhre, G., Nagashima, T., Naik, V., Rumbold, S. T., Skeie, R., Sudo, K., Szopa, S., Takemura, T., Voulgarakis, A., Yoon, J.-H., and Lo, F.: Radiative forcing in the ACCMIP historical and future climate simulations, Atmos. Chem. Phys., 13, 2939-2974, doi:10.5194/acp-13-2939-2013, 2013a.

Shindell, D. T., Faluvegi, G., Nazarenko, L, Bowman, K., Lamarque, J.-F., Voulgarakis, A., Schmidt, G., Pechony, O., and Reudy, 
R.: Attribution of historical whole atmosphere ozone forcing, Nature Climate Change, 3, 567-570, doi:10.1038/nclimate1835, 2013b.

Shindell, D. T., Pechony, O., Voulgarakis, A., Faluvegi, G., Nazarenko, L., Lamarque, J.-F., Bowman, K., Milly, G., Kovari, B., Ruedy, R., and Schmidt, G. A.: Interactive ozone and methane chemistry in GISS-E2 historical and future climate simulations, Atmos. Chem. Phys., 13, 2653-2689, doi:10.5194/acp-13-26532013, 2013c.

Shindell, D. T., Faluvegi, G., Rotstayn, L., and Milly, G.: Spatial patterns of radiative forcing and surface temperature response, J. Geophys. Res., 120, 5385-5403, 2015.

Shine, K. P., Bourqui, M. S., de Forster, P. M., Hare, S. H. E., Langematz, U., Braesicke, P., Grewe, V., Ponater, M., Schnadt, C., Smith, C. A., Haigh, J. D., Austin, J., Butchart, N., Shindell, D. T., Randel, W. J., Nagashima, T., Portmann, R. W., Solomon, S., Seidel, D. J., Lanzante, J., Klein, S., Ramaswamy, V., and Schwarzkopf, M. D.: A comparison of model-simulated trends in stratospheric temperatures, Q. J. Roy. Meteorol. Soc., 129, 15651588, 2003.

Smith, S. J., van Aardenne, J., Klimont, Z., Andres, R. J., Volke, A., and Delgado Arias, S.: Anthropogenic sulfur dioxide emissions: 1850-2005, Atmos. Chem. Phys., 11, 1101-1116, doi:10.5194/acp-11-1101-2011, 2011.

Son, S.-W., Polvani, L. M., Waugh, D. W., Akiyoshi, H., Garcia, R., Kinnison, D., Pawson, S., Rozanov, E., Shepherd, T. G., and Shibata, K.: The impact of stratospheric ozone recovery on the Southern hemisphere westerly jet, Science, 320, 1486-1489, 2008.

Son, S.-W., Gerber, E. P., Perlwitz, J., Polvani, L. M., Gillett, N. P., Seo, K. H., Eyring, V., Shepherd, T. G., Waugh, D., Akiyoshi, H., Austin, J., Baumgaertner, A., Bekki, S., Braesicke, P., Bruhl, C., Butchart, N., Chipperfield, M. P., Cugnet, D., Dameris, M., Dhomse, S., Frith, S., Garny, H., Garcia, R., Hardiman, S. C., Jockel, P., Lamarque, J. F., Mancini, E., Marchand, M., Michou, M., Nakamura, T., Morgenstern, O., Pitari, G., Plummer, D. A., Pyle, J., Rozanov, E., Scinocca, J. F., Shibata, K., Smale, D., Teyssedre, H., Tian, W., and Yamashita, Y.: Impact of Stratospheric Ozone on Southern Hemisphere Circulation Change: A Multimodel Assessment, J. Geophys. Res., 115, D00M07, doi:10.1029/2010JD014271, 2010.

SPARC CCMVal: SPARC Report on the Evaluation of ChemistryClimate Models, edited by: Eyring, V., Shepherd, T. G., and Waugh, D. W., SPARC Report No. 5, WCRP-132, WMO/TDNo. 1526, 2010.

Stevenson, D. S., Dentener, F. J., Schultz, M. G., Ellingsen, K., van Noije, T. P. C., Wild, O., Zeng, G., Amann, M., Atherton, C. S., Bell, N., Bergmann, D. J., Bey, I., Butler, T., Cofala, J., Collins, W. J., Derwent, R. G., Doherty, R. M., Drevet, J., Eskes, H. J., Fiore, A. M., Gauss, M., Hauglustaine, D. A., Horowitz, L. W., Isaksen, I. S. A., Krol, M. C., Lamarque, J. F., Lawrence, M. G., Montanaro, V., Muller, J. F., Pitari, G., Prather, M. J., Pyle, J. A., Rast, S., Rodriguez, J. M., Sanderson, M. G., Savage, N. H., Shindell, D. T., Strahan, S. E., Sudo, K., and Szopa, S.: Multimodel ensemble simulations of present-day and near-future tropospheric ozone, J. Geophys. Res.-Atmos., 111, D08301, doi:10.1029/2005JD006338, 2006.

Stevenson, D. S., Young, P. J., Naik, V., Lamarque, J.-F., Shindell, D. T., Voulgarakis, A., Skeie, R. B., Dalsoren, S. B., Myhre, G.,
Berntsen, T. K., Folberth, G. A., Rumbold, S. T., Collins, W. J., MacKenzie, I. A., Doherty, R. M., Zeng, G., van Noije, T. P. C., Strunk, A., Bergmann, D., Cameron-Smith, P., Plummer, D. A., Strode, S. A., Horowitz, L., Lee, Y. H., Szopa, S., Sudo, K., Nagashima, T., Josse, B., Cionni, I., Righi, M., Eyring, V., Conley, A., Bowman, K. W., Wild, O., and Archibald, A.: Tropospheric ozone changes, radiative forcing and attribution to emissions in the Atmospheric Chemistry and Climate Model Intercomparison Project (ACCMIP), Atmos. Chem. Phys., 13, 3063-3085, doi:10.5194/acp-13-3063-2013, 2013.

Teixeira, J., Waliser, D., Ferraro, R., Gleckler, P., Lee, T., and Potter, G.: Satellite Observations for CMIP5: The Genesis of Obs4MIPs, B. Am. Meteorol. Soc., 95, 1329-1334, 2014.

Teng, H., Washington, W. M., Branstator, G., Meehl, G. A., and Lamarque, J. F.: Potential impacts of Asian carbon aerosols on future US warming, Geophys. Res. Lett., 39, L11703, doi:10.1029/2012GL051723, 2012.

Textor, C., Schulz, M., Guibert, S., Kinne, S., Balkanski, Y., Bauer, S., Berntsen, T., Berglen, T., Boucher, O., Chin, M., Dentener, F., Diehl, T., Easter, R., Feichter, H., Fillmore, D., Ghan, S., Ginoux, P., Gong, S., Grini, A., Hendricks, J., Horowitz, L., Huang, P., Isaksen, I., Iversen, I., Kloster, S., Koch, D., Kirkevåg, A., Kristjansson, J. E., Krol, M., Lauer, A., Lamarque, J. F., Liu, X., Montanaro, V., Myhre, G., Penner, J., Pitari, G., Reddy, S., Seland, Ø., Stier, P., Takemura, T., and Tie, X.: Analysis and quantification of the diversities of aerosol life cycles within AeroCom, Atmos. Chem. Phys., 6, 1777-1813, doi:10.5194/acp-6-1777-2006, 2006.

van Vuuren, D. P., Kriegler, E., O’Neill, B. C., Ebi, K. L., Riahi, K., Carter, T. R., Edmonds, J., Hallegatte, S., Kram, T., Mathur, R., and Winkler, H.: A new scenario framework for climate change research: scenario matrix architecture, Clim. Change, 122, 373386, 2014.

Voulgarakis, A., Naik, V., Lamarque, J.-F., Shindell, D. T., Young, P. J., Prather, M. J., Wild, O., Field, R. D., Bergmann, D., CameronSmith, P., Cionni, I., Collins, W. J., Dalsøren, S. B., Doherty, R. M., Eyring, V., Faluvegi, G., Folberth, G. A., Horowitz, L. W., Josse, B., MacKenzie, I. A., Nagashima, T., Plummer, D. A., Righi, M., Rumbold, S. T., Stevenson, D. S., Strode, S. A., Sudo, K., Szopa, S., and Zeng, G.: Analysis of present day and future $\mathrm{OH}$ and methane lifetime in the ACCMIP simulations, Atmos. Chem. Phys., 13, 2563-2587, doi:10.5194/acp-13-25632013, 2013.

WMO: Scientific Assessment of Ozone Depletion 2010, Global Ozone Research and Monitoring Project Report, 52, World Meteorological Organisation, Geneva, 2010.

WMO: Scientific Assessment of Ozone Depletion 2014, Global Ozone Research and Monitoring Project Report, 55, World Meteorological Organisation, Geneva, 2014.

Young, P. J., Archibald, A. T., Bowman, K. W., Lamarque, J.-F., Naik, V., Stevenson, D. S., Tilmes, S., Voulgarakis, A., Wild, O., Bergmann, D., Cameron-Smith, P., Cionni, I., Collins, W. J., Dalsøren, S. B., Doherty, R. M., Eyring, V., Faluvegi, G., Horowitz, L. W., Josse, B., Lee, Y. H., MacKenzie, I. A., Nagashima, T., Plummer, D. A., Righi, M., Rumbold, S. T., Skeie, R. B., Shindell, D. T., Strode, S. A., Sudo, K., Szopa, S., and Zeng, G.: Preindustrial to end 21 st century projections of tropospheric ozone from the Atmospheric Chemistry and Climate Model Intercom- 
parison Project (ACCMIP), Atmos. Chem. Phys., 13, 2063-

2090, doi:10.5194/acp-13-2063-2013, 2013. 